\title{
FINAL REPORT - UFP RESTART AND SPARGER TESTING
}

OCTOBER 2004

ENGINEERING DEVELOPMENT LABORATORY

HANFORD RIVER PROTECTION PROJECT - WTP

SAVANNAH RIVER NATIONAL LABORATORY

Westinghouse Savannah River Company

Savannah River Site

Aiken, SC 29808

Prepared for the U.S. Department of Energy Under Contract Number DEAC09-96SR18500

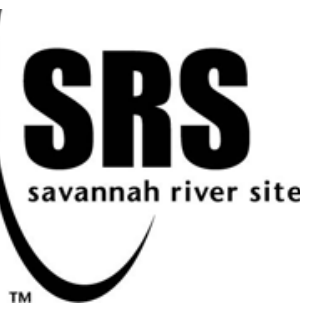


WSRC-TR-2004-00488, REVISION 0

SRNL-RPP-2004-00066, REVISION 0

DISCLAIMER

This report was prepared for the United States Department of Energy under Contract No. DE-AC09-96SR18500 and is an account of work performed under that contract. Neither the United States Department of Energy, nor WSRC, nor any of their employees makes any warranty, expressed or implied, or assumes any legal liability or responsibility for accuracy, completeness, or usefulness, of any information, apparatus, or product or process disclosed herein or represents that its use will not infringe privately owned rights. Reference herein to any specific commercial product, process, or service by trade name, trademark, name, manufacturer or otherwise does not necessarily constitute or imply endorsement, recommendation, or favoring of same by Westinghouse Savannah River Company or by the United States Government or any agency thereof. The views and opinions of the authors expressed herein do not necessarily state or reflect those of the United States Government or any agency thereof.

Printed in the United States of America

Prepared For

U.S. Department of Energy 
Key Words:

Pulse Jet Mixer

Sparger

Retention:

Permanent

Key WTP R\&T References:

Test Plan WSRC-TR-2003-00532

Test Exceptions

24590-WTP-TEF-RT-04-006

Test Scoping Statement S-200

\section{FINAL REPORT - UFP RESTART AND SPARGER TESTING}

\section{Hector N. Guerrero 786-5A \\ Michael Restivo 786-5A}

\section{OCTOBER 2004}

Westinghouse Savannah River Company Savannah River Site

Aiken, SC 29808

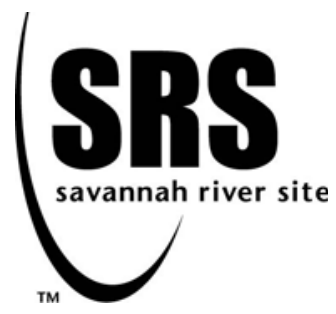


WSRC-TR-2004-00488, REVISION 0

SRNL-RPP-2004-00066, REVISION 0

\section{REVIEWS AND APPROVALS}

Hector N. Guerrero \&DL, Hanford RPP-WTP, SRNL

Date

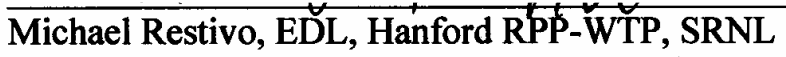

Date

D. J. Aldamson, Technical Reviewer

Date

Dan Burns, Manager, Level 4 Manager, Hanford RPP-WTP, SRNL

Date

Steve Barnes, RPP Customer

Date 


\section{TABLE OF CONTENTS}

LIST OF FIGURES ................................................................................................................... iv

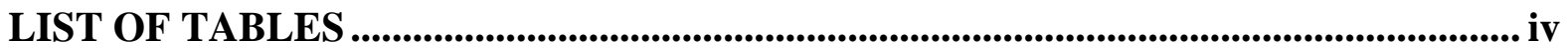

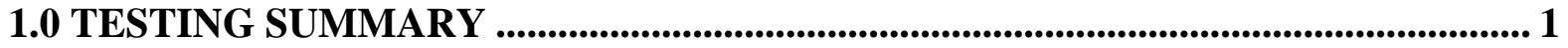

1.1 OBJECTIVES ................................................................................................................ 2

1.2 TEST EXCEPTION ........................................................................................................ 3

1.3 RESULTS AND PERFORMANCE AGAINST SUCCESS CRITERIA .................. 3

1.4 QUALITY REQUIREMENTS..................................................................................... 3

1.5 R\&T TEST CONDITIONS ........................................................................................... 3

1.6 SIMULANT USE............................................................................................................... 4

1.6.1 Full-Scale Sparger Test Simulant ...................................................................................... 4

1.6.2 UFP Restart Test Simulant......................................................................................... 5

1.6.3 UFP Glass Beads Testing................................................................................................... 6

1.7 DISCREPANCIES AND FOLLOW-ON TESTS ........................................................... 7

2.0 DISCUSSION ........................................................................................................................ 9

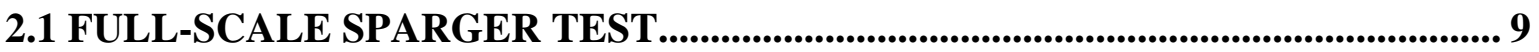

2.1.1 Objective .......................................................................................................................... 9

2.1.2 Test Apparatus .............................................................................................................. 9

2.1.3 Test Procedure.................................................................................................................. 12

2.1.4 Test Results ...................................................................................................................... 12

2.1.4.1 Test 1 - Laponite ............................................................................................................... 12

2.1.4.2 Test 2 - Laponite ............................................................................................................. 14

2.1.4.3 Test 3 - Kaolin ................................................................................................. 19

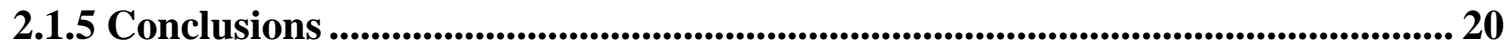

2.2 UFP RESTART TESTING.................................................................................... 20

2.2.1 Objective .......................................................................................................................... 20

2.2.2 Test Apparatus .................................................................................................................. 21

2.2.3 Test Procedure................................................................................................................ 23

2.2.4 Test Results ................................................................................................................ 23

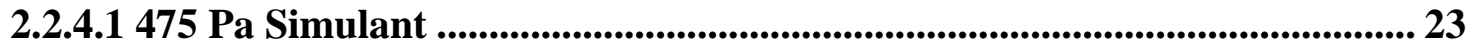

2.2.4.2 596Pa Simulant Test .................................................................................................. 24

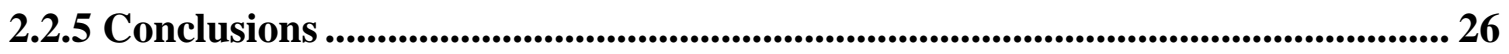

2.3 UFP GLASS BEADS TESTING .............................................................................. 28

2.3.1 Objective .................................................................................................................... 28

2.3.2 Test Apparatus .................................................................................................................... 28

2.3.3 Test Procedure....................................................................................................... 28

2.3.4 Test Results .............................................................................................................. 29

2.3.5 Conclusions ......................................................................................................................... 29

3.0 FUTURE WORK ............................................................................................................... 33

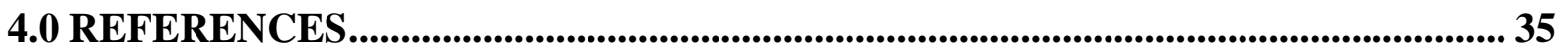




\section{LIST OF FIGURES}

Figure 2-1. Full-Scale Single Sparger Test Loop …...................................................... 10

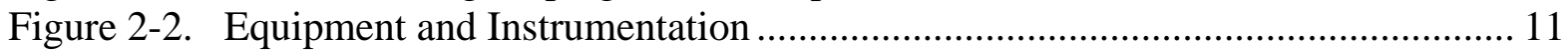

Figure 2-3. Test Rig and Sparger Isolation Valve .......................................................... 11

Figure 2-4. Test 1 Full-Scale Sparger Test Results with 132.2 Pa Y.S. Laponite................ 13

Figure 2-5. C Crack Propagation During Sparger Testing in Laponite................................. 14

Figure 2-6. Test 2 - 132 Pascal Laponite/Bentonite, Run till Breakthrough ........................ 15

Figure 2-7. Test 2 - 132 Pascal Laponite/Bentonite, Run including Sparging Studies ........ 15

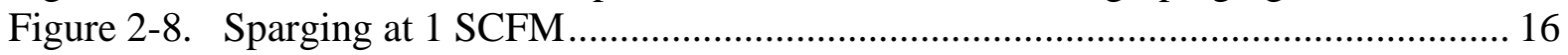

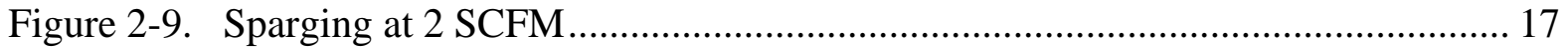

Figure 2-10. Schematic Diagram Illustrating Bulk Movement of Laponite during Sparging

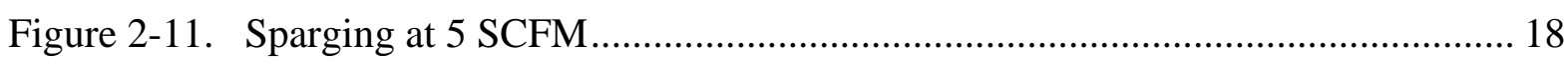

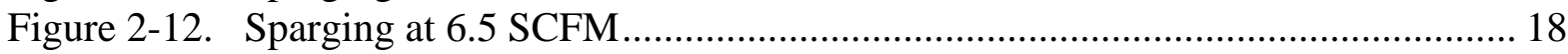

Figure 2-13. Test 3 - 30 Pascal Kaolin, Run till Breakthrough .......................................... 19

Figure 2-14. Test Stand Used in UFP Restart Testing...................................................... 21

Figure 2-15. Elevation View of UFP Restart Test Vessel ............................................... 22

Figure 2-16. Test 1 Cumulative Cycles Required for UFP Restart and PJM Drive Distance

Figure 2-17. Test 2 Cumulative Cycles and PJM Drive Distance Required for UFP Restart

25

Figure 2-18. Tests with 600 Pa Clay............................................................................ 27

Figure 2-19. Bubbles along Tank Wall Showing Jelled Simulant during Pulsing (600 Pa) 27

Figure 2-20. Sparger Bottoms Used in UFP Glass Beads Test......................................... 28

\section{LIST OF TABLES}

Table 1-1. Test Objectives ....................................................................................... 2

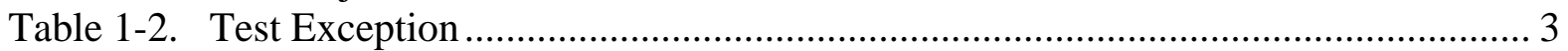

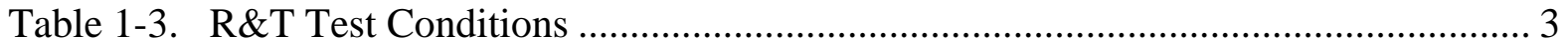

Table 1-4. Rheological Properties of Kaolin:Bentonite Mixture ........................................ 5

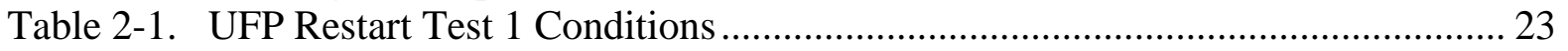

Table 2-2. UFP Restart Test 1 Results....................................................................... 24

Table 2-3. UFP Restart Test 2 Conditions .................................................................... 25

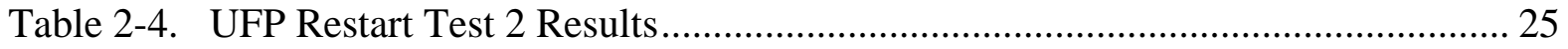

Table 2-5. Glass Bead Behavior under Various Sparger Heights and Air Flows for Flat-

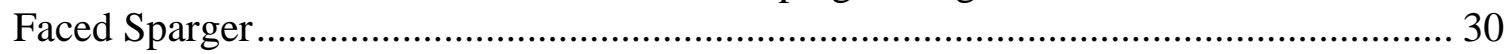

Table 2-6. Glass Bead Behavior under Various Sparger Heights and Air Flows for Notched

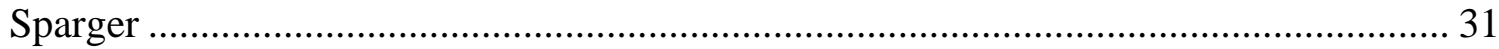


WSRC-TR-2004-00488, REVISION 0

SRNL-RPP-2004-00066, REVISION 0

\subsection{TESTING SUMMARY}

Following a Design Basis Event (DBE), potential plugging of the PJM systems is highly probable after air compressors and/or electric power become unavailable for up to $100 \mathrm{hrs}$. Under such conditions, the rheologically bounding yield stress of the pretreated sludge simulant could reach 300-625 Pa. (Defined in WTP-RPP-100, Rev. 0, Sec. 6.1. [1] and WTP-RPP-98, Rev. 0, Secs. 5.1 and 5.2 [2].) The tests covered under this report are conservative since this range of bounding yield stress is based on the settled solids component in the tank. Also, note that CCN 065607 states that the design basis is $70 \mathrm{~Pa}$ for "gelled material" over the entire tank. Three issues must be addressed by these tests:

- Determine the required pressure and air flow to overcome the plugged sparger tube resistance following a DBE event.

- Can the UFP PJMs be restarted with or without assistance from air spargers?

- Show that solids can be mixed by air spargers following a DBE to allow generated hydrogen gas to rise and be vented to the vessel head space. This is to limit hydrogen concentrations below LFL level.

In the first test, a full-scale sparger was simulated by a 2"dia. Schedule 160 pipe, installed in an 18” diameter plastic tank, 37' high (full scale height), 6” from the bottom. The bottom 5-ft. lower section was clear to facilitate visual observations. Two simulants were used: a $120 \mathrm{~Pa}$ Laponite solution and a $30 \mathrm{~Pa} / 30$ cP kaolin:bentonite clay mixture, which filled the tank to the 32' level. The first test with $120 \mathrm{~Pa}$ Laponite demonstrated breakthrough at an air pressure of 14.6 psig. The second test with the clay simulant resulted in breakthrough at 16.7 psig. Given the specific gravities of these simulants, the breakthrough pressures are very close to the hydrostatic pressures corresponding to the simulant elevations inside the sparger.

The CRV test stand at the Engineering Development Laboratory, SRNL, was used to simulate the UFP at 1/4-scale, where the tank diameter was 40.5 -inches. The simulant was a $30 \mathrm{~Pa} / 30 \mathrm{cP}$ kaolin:bentonite mixture loaded with $3.3 \mathrm{wt} \%$ dry laponite, which successfully achieved a $596 \mathrm{~Pa}$ yield stress (vane method) after 14 hrs. However, it apparently had a thicker consistency than the $30 \mathrm{~Pa} / 30 \mathrm{cP}$ rheology of real waste under flowing conditions. The vessel was filled to a H/D of 1.38 and the PJMs were initially filled to approximately full height (39”). During the initial drive phase, starting from the full PJM level, application of the same PJM air pressure during normal operation did push the gelled simulant the full travel distance. But on the refill or suction phase, the maximum simulant height in the PJM was only about a third (9.2") of the original travel (27”). After 20 cycles of PJM operation only, air sparging, starting at $7 \mathrm{scfm}$, increasing to $10 \mathrm{scfm}$ was introduced. This increased the PJM drive distance to a stable value of $64 \%$ of the full travel after 327 cycles. Visual observation suggests that the simulant was moving up and down as a solid plug and that the cavern may be very limited. Thus, air sparging did not reestablish full PJM operation, but this could be due to the higher consistency of the simulant as compared to the actual waste. 
A third test utilized $5 \mathrm{~mm}$ glass beads deposited at the bottom of the CRV vessel, which was filled with water. Enough glass beads were added to cover the tank bottom surface with a onebead-thick layer. Based on empirical correlations, the glass beads simulate the behavior of solid particles in the waste. Two spargers were tested: a 2" dia. Sch. 160 pipe with straight end, and a 2”dia. Sch. 160 pipe with 4 (45 deg) notches around the perimeter, 3/4” deep. The objectives were to determine the required distance between the sparger end and the vessel bottom, air pressures, and air flows required to lift the glass beads off the vessel bottom. The test started with the spargers 6 inches from the bottom. For the flat faced sparger, no lifting was observed up to $50 \mathrm{scfm}$. Liftoff was observed only when the sparger end was 1 ” off the bottom. At $10 \mathrm{scfm}$, glass beads started to be lifted off. At $50 \mathrm{scfm}$, approximately 300 beads (or approximately $1.5 \%$ of all beads) were lifted off. A 30" diameter affected zone was observed where the bed was vibrating. For the notched sparger, no liftoff was observed until the sparger was 1 " from the bottom with $40 \mathrm{scfm}$ (approx. 10 beads or $0.05 \%$ of the total). At $50 \mathrm{scfm}, 50 \%$ more beads were lifted off and a 12" diameter of bulk movement and 24" affected zone was established.

\subsection{OBJECTIVES}

\section{Table 1-1. Test Objectives}

\begin{tabular}{|c|c|c|}
\hline Test Objective & $\begin{array}{c}\text { Objective } \\
\text { Met } \\
(\mathbf{Y} / \mathbf{N})\end{array}$ & Discussion \\
\hline $\begin{array}{l}\text { 1. Perform single prototypic tube } \\
\text { sparging tests to determine the } \\
\text { required pressure and air flow } \\
\text { rate to overcome sparger } \\
\text { plugging after postulated loss of } \\
\text { air or venting causing simulant } \\
\text { to equalize inside sparger tube }\end{array}$ & $\mathrm{Y}$ & $\begin{array}{l}\text { A full-scale ( } 2 \text { ”) sparger tube was } \\
\text { installed inside a } 37 \mathrm{ft} \text {. tall tank } \\
\text { filled with simulant with high yield } \\
\text { stress. The tests determined the air } \\
\text { pressures and flow rates necessary } \\
\text { for breakthrough. }\end{array}$ \\
\hline $\begin{array}{l}\text { 2. Simulate PJM restart in a } \\
\text { prototypic UFP tank with high } \\
\text { aspect ratio }(\mathrm{H} / \mathrm{D}=1.42) \text { and } \\
\text { filled with high yield stress } \\
\text { simulant (Y.S. = 300-625 Pa) } \\
\text { after a postulated shutdown of } \\
100 \text { hrs. }\end{array}$ & $\mathrm{Y}$ & $\begin{array}{l}\text { Tests were performed to determine if } \\
\text { PJMs could be restarted under } \\
\text { bounding rheological conditions } \\
\text { with and without sparging. Tests } \\
\text { were also performed to determine } \\
\text { what procedures and restart time } \\
\text { were necessary to achieve successful } \\
\text { restart. Due to a limited volume of } \\
\text { clay simulant available, the UFP } \\
\text { tank was filled to a H/D=1.38 only. }\end{array}$ \\
\hline $\begin{array}{l}\text { 3. Determine required air flow and } \\
\text { distance from end of sparging } \\
\text { tube and vessel bottom that } \\
\text { causes } 5 \text { mm glass beads to lift } \\
\text { off the tank bottom. }\end{array}$ & $\mathrm{Y}$ & $\begin{array}{l}\text { Tests were performed with two 2"D } \\
\text { spargers with different nozzle } \\
\text { designs at various air flows and } \\
\text { sparger-to-vessel bottom distances. }\end{array}$ \\
\hline
\end{tabular}


WSRC-TR-2004-00488, REVISION 0

SRNL-RPP-2004-00066, REVISION 0

\subsection{TEST EXCEPTION}

Table 1-2. Test Exception

\begin{tabular}{|l|l|}
\hline List Test Exception & Describe Test Exceptions \\
\hline Exception & Added single prototypic sparger test, UFP \\
24590-WTP-TEF-RT-04-00024, Rev. 0 & restart test, and glass bead lift-off test to \\
& Test Plan WSRC-TR-2003-00532, \\
& SRT-RPP-2003-00235. \\
\hline
\end{tabular}

\subsection{RESULTS AND PERFORMANCE AGAINST SUCCESS CRITERIA}

No success criteria specified.

\subsection{QUALITY REQUIREMENTS}

This work was conducted in accordance with the RPP-WTP QA requirements specified for work conducted by SRTC as identified in DOE IWO MOSRLE60. SRTC has provided matrices to WTP demonstrating compliance of the SRTC QA program with the requirements specified by WTP. Specific information regarding the compliance of the SRTC QA program with RW-0333P, Revision 10, NQA-1 1989, Part 1, Basic and Supplementary Requirements and NQA-2a 1990, Subpart 2.7 is contained in these matrices.

\subsection{R\&T TEST CONDITIONS}

Table 1-3. $\quad$ R\&T Test Conditions

\begin{tabular}{|l|l|}
\hline List R\&T Test Conditions & Were Test Conditions Followed? \\
\hline $\begin{array}{l}\text { 1. Full-scale 2”D sparger tubes were built } \\
\text { and installed inside a 37-ft.-tall tank to } \\
\text { simulate UFP conditions. Simulants to } \\
\text { be used were } 120 \text { Pa Y.S. Laponite and } \\
\text { 30 Pa/30 cP Kaolin:bentonite simulant. }\end{array}$ & $\begin{array}{l}\text { installed inside a } 37 \mathrm{ft} \text {. tall tank, 18” in } \\
\text { diameter. Simulants were made and tested. }\end{array}$ \\
\hline
\end{tabular}


Table 1-3. R\&T Test Conditions - continued

\begin{tabular}{|c|c|}
\hline List R\&T Test Conditions & Were Test Conditions Followed? \\
\hline $\begin{array}{l}\text { 2. A } 1 / 4 \text { scale tank with } 6 \text { PJM tubes was to } \\
\text { be used to simulate the CRV tank. The } \\
\text { tank was required to be filled to a H/D } \\
\text { of } 1.42 \text {. The high end of the simulant } \\
\text { rheological conditions ( } 625 \text { Pa Y.S.) was } \\
\text { to be used. }\end{array}$ & $\begin{array}{l}\text { The CRV test vessel was modified to } \\
\text { simulate the UFP by removing the charge } \\
\text { vessels. The amount of simulant available } \\
\text { was sufficient only to fill the tank to a } \\
\mathrm{H} / \mathrm{D}=1.38 \text {. } \\
\text { A recipe developed by Battelle and SRNL } \\
\text { using mixture of Laponite and } \\
\text { kaolin:bentonite was successful in } \\
\text { simulating } 625 \mathrm{~Pa} \mathrm{Y} \text {.S. requirement, but } \\
\text { did not follow a } 30 \mathrm{~Pa} / 30 \mathrm{cP} \text { flow curve of } \\
\text { the actual waste during normal operation. }\end{array}$ \\
\hline $\begin{array}{l}\text { 3. Water was to be used as simulant, filling } \\
\text { the tank to a H/D=1. } 5 \mathrm{~mm} \text { glass beads } \\
\text { sufficient to cover } 100 \% \text { of the tank } \\
\text { bottom area, to a one-bead-thick layer. } \\
\text { Two spargers, } 2 \text { "Sch. } 160 \text { stainless steel } \\
\text { pipe, were to be used, where one sparger } \\
\text { had a flat bottom, and the other had } 4 \\
\text { (45 deg) notches around the perimeter, } \\
\text { 3/4” deep. Airflow rates were to range } \\
\text { from } 1 \text { scfm to } 10 \text { scfm per } \mathrm{ft}^{2} \text { of tank } \\
\text { area. }\end{array}$ & $\begin{array}{l}\text { All requirements were met, except for } \\
\text { maximum sparger air flow, which was } \\
50 \mathrm{scfm}^{2} \text { (building air limit), or } 5.7 \mathrm{scfm} \\
\text { per } \mathrm{ft}^{2} \text { of tank area. }\end{array}$ \\
\hline
\end{tabular}

\subsection{SIMULANT USE}

\subsubsection{Full-Scale Sparger Test Simulant}

The Test Specification [1] required two simulants: 1) Laponite with a yield stress of 100 $120 \mathrm{~Pa}$ and 2) kaolin:bentonite mixture with the Bingham plastic yield stress of $30 \mathrm{cP}$ and consistency of $30 \mathrm{cP}$. To achieve the $120 \mathrm{~Pa}$ requirement for Laponite, a $65 \mathrm{~Pa}$ Laponite previously made up was spiked with 0.54 weight percent dry Laponite. The mixture was agitated overnight (more than $12 \mathrm{hrs}$ ) by two $3 / 4 \mathrm{hp}$ mechanical agitators in a mixing tank to get rid of "fish eyes" or lumps of dry powder. Measurement of the yield stress by the vane method achieved the following results:

Sample 1-133.6 Pascal

Sample 2-130.2 Pascal

Average-131.9 Pascal

For the kaolin:bentonite simulant, the rheological properties are summarized in Table 1-4, where the more representative down curve is provided. 
WSRC-TR-2004-00488, REVISION 0

SRNL-RPP-2004-00066, REVISION 0

Table 1-4. Rheological Properties of Kaolin:Bentonite Mixture

\begin{tabular}{|c|c|c|}
\hline Model/model Parameter & $\begin{array}{c}\text { Run \#1 } \\
\text { Parameter Value }\end{array}$ & $\begin{array}{c}\text { Run \#2 } \\
\text { Parameter Value }\end{array}$ \\
\hline Bingham Plastic & $\begin{array}{c}\text { Kaolin-Bent 5-12-04 } \\
\text { 7:29PM Calib. Test }\end{array}$ & $\begin{array}{c}\text { Kaolin-Bent 5-12-04 } \\
\text { 7:29PM Calib. Test }\end{array}$ \\
\hline Shear rate range data fitted $\left(\mathrm{sec}^{-1}\right)$ & Down Curve 50-300 & Down Curve 50-300 \\
\hline$\tau_{\mathrm{O}}{ }^{\mathrm{B}}$ - the Bingham yield stress $(\mathrm{Pa})$ & 29.13 & 29.56 \\
\hline$\eta_{\mathrm{P}}$ - the plastic viscosity (cP) & 41.6 & 42.18 \\
\hline $\mathrm{R}^{2}$ - correlation coefficient & .9750 & .9744 \\
\hline Herschel-Bulkley: & $\begin{array}{c}\text { Kaolin-Bent } 5-12-04 \\
\text { 7:29PM Calib. Test }\end{array}$ & $\begin{array}{c}\text { Kaolin-Bent } 5-12-04 \\
\text { 7:29PM Calib. Test }\end{array}$ \\
\hline Shear rate range data fitted $\left(\mathrm{sec}^{-1}\right)$ & Down Curve 50-300 & Down Curve 50-300 \\
\hline $\begin{array}{l}\tau_{\mathrm{O}}{ }^{\mathrm{H}} \text { - the Herschel-Bulkley yield stress } \\
(\mathrm{Pa})\end{array}$ & 12.6 & 12.0 \\
\hline $\begin{array}{l}\mathrm{k} \text { - the Herschel-Bulkley consistency } \\
\text { coefficient }\left(\mathrm{Pa}-\mathrm{sec}^{\mathrm{b}}\right)\end{array}$ & 5.78 & 6.35 \\
\hline $\begin{array}{l}\text { b - the Hershel-Bulkley power law } \\
\text { exponent }\end{array}$ & 0.2779 & 0.2666 \\
\hline $\mathrm{R}^{2}-$ correlation coefficient & .9992 & .9992 \\
\hline $\begin{array}{l}\text { * - Denotes negative value } \\
\text { Physical Properties } \\
\text { Total Solids } \\
\text { Density } \\
\mathbf{2 4 . 9 1} \mathbf{~ w t} \% \\
\mathbf{1 . 1 8 4 4} \mathbf{g} / \mathbf{m L}\end{array}$ & & \\
\hline
\end{tabular}

\subsubsection{UFP Restart Test Simulant}

The simulant to be used in the UFP Restart Test was to mimic the yield stress of the actual waste after a postulated absence of mixing of $100 \mathrm{hrs}$ or 4 days. This yield stress criterion was 300-625 Pa. SRNL and Battelle collaborated in developing a kaolin:bentonite:Laponite mixture to meet the 300-625 Pa yield stress criterion. The first simulant utilized a $30 \mathrm{~Pa} / 30$ cP clay previously used in CRV testing, to which was added $2.54 \mathrm{wt} \%$ Laponite. The kaolin:bentonite mixture was first mixed in a 300 gallon tank with two mechanical agitators. One agitator had four sets of vanes, the top one being 6 inches below the surface. This created a vortex into which dry laponite was added. After one hour of mixing, no "fish eyes" were detected and since the simulant started to show signs of thickening, the mixture was pumped immediately into the test vessel. Samples taken at this time resulted in a $475 \mathrm{~Pa}$ yield stress clay after $24 \mathrm{hrs}$, and then were used in the first UFP Restart test. 
WSRC-TR-2004-00488, REVISION 0

SRNL-RPP-2004-00066, REVISION 0

The actual measurements using the vane measurement technique were as follows:

$\begin{array}{llll}\text { Sample 1 Run 1 } & 507 \mathrm{~Pa} & \text { Sample 2 Run 1 } & 525 \mathrm{~Pa} \\ \text { Sample 1 Run 2 } & 406 \mathrm{~Pa} & \text { Sample 2 Run 2 } & 486 \mathrm{~Pa} \\ \text { Sample 1 Run 3 } & 457 \mathrm{~Pa} & & \\ & & \text { Sample 2 Average } & 506 \mathrm{~Pa}\end{array}$

Due to the desire to meet the high end of the 300-625 Pa requirement, a second recipe was developed which called for $3.3 \mathrm{wt} \%$ Laponite. The measured yield stress after a 14-hr wait and using the vane measurement technique is as follows:

\begin{tabular}{|c|c|}
\hline Samp & \\
\hline Run 1 & $637.5 \mathrm{~Pa}$ \\
\hline Run 2 & 657.3 Pa \\
\hline Run 3 & 573.3 $\mathrm{Pa}$ \\
\hline Run 4 & 572.2 Pa \\
\hline
\end{tabular}

Sample \#2

Run $1 \quad 601.5 \mathrm{~Pa}$

Run 2 607.7 Pa

\section{Sample \#3}

Run $1 \quad 545.1 \mathrm{~Pa}$

Run $2 \quad 644.9 \mathrm{~Pa}$

Run $3 \quad 567.6 \mathrm{~Pa}$

Run $4557.5 \mathrm{~Pa}$

\section{Overall Average $=596.5 \mathrm{~Pa}$, standard deviation $=39.2 \mathrm{~Pa}$}

The variation in yield stresses for different samples and runs is typical for this thick material. Further, during the filling of the tank and calibration of the level probes (which required operation of the PJMs), the simulant was thickening very quickly. The high consistency (higher than $30 \mathrm{cP}$ ) prevented the level to be pulled up to the 40” required level. The start level for the Restart test was 1" below this level.

\subsubsection{UFP Glass Beads Testing}

- Water was used as simulant for the UFP glass beads lift-off test.

- Glass bead diameter was $5 \mathrm{~mm}$ and a total mass of $5 \mathrm{~kg}$, sufficient to cover the bottom surface of the tank to a thickness of 1 bead was added to the tank. 


\subsection{DISCREPANCIES AND FOLLOW-ON TESTS}

The Test Specification called for a simulant for the UFP Restart test to meet a 300-625 Pa yield stress criterion. This was met with the kaolin:bentonite:laponite simulant developed. However, once the simulant was put into motion by PJM operation, the flowing simulant should exhibit the normal Bingham plastic yield stress of $30 \mathrm{~Pa}$ and consistency of $30 \mathrm{cP}$. SRNL attempted to do flow curve measurements on this simulant, but the results were inconsistent for up and down flow curves. This required development of new technique to measure the rheology of such a thick material, but which was not approved. The initial efforts indicated significantly higher consistency than $30 \mathrm{cP}$. This explains why even when the PJMs were able to push the simulant out of the pulse tubes, the suction phase was limited to around half the normal drive distance. A very small cavern was evident from the visible plug motion of the bulk of the simulant. Consequently, the results were not fully successful due to the limited PJM drive distance.

Battelle was able to develop a new recipe that met the $625 \mathrm{~Pa}$ yield stress criterion for jelled material and the $30 \mathrm{~Pa} / 30 \mathrm{cP}$ rheology for flowing conditions. Follow-on tests using this material could be performed if required. 
WSRC-TR-2004-00488, REVISION 0

SRNL-RPP-2004-00066, REVISION 0

This page intentionally left blank. 
WSRC-TR-2004-00488, REVISION 0

SRNL-RPP-2004-00066, REVISION 0

\subsection{DISCUSSION}

This section is organized into three major subsections relating to the three individual tests. These subsections will include descriptions of the respective test apparatus, procedures, and results. All measurements were obtained using specified QA Requirements on Measuring and Test Equipment, Sec. 1.4.

\subsection{FULL-SCALE SPARGER TEST}

\subsubsection{Objective}

The objective of this test was to determine the required pressure and air flow to overcome the plugged sparger tube resistance following a DBE event.

\subsubsection{Test Apparatus}

A 2-inch diameter stainless steel pipe, Sch 80, representing a full-scale sparger, was installed in a 37-ft. high PVC tank, 18-inches inside diameter, with a $5 \mathrm{ft}$. high clear acrylic lower section to facilitate visual observations. The simulant level inside the tank was 32'-11' and matched the full-scale UFP tank level. The bottom of the model sparger was set 6 inches above the bottom of the tank.

Figure 2-1 is a simplified P\&I schematic of the test loop. The model sparger was connected to the building air supply through a 2-inch ball valve at its upper end, a Kurz mass air flow meter, pressure regulator, and a $1 / 2$-inch ball valve. The Kurz mass air flow meter, 0-25 scfm, measured the air flow in scfm. The 2 -inch ball valve allowed visual observation of the interior of the sparger. The pressure in the line just upstream of the 2-inch ball valve was measured with a 0-150 psig Rosemount pressure transmitter. The temperature in the tank was measured with a Type E thermocouple. All electronic instrumentation (mass flow meter, pressure transmitter, and tank thermocouple) were connected to a PC-based data acquisition system.

In addition to the sparger tank itself, a mixing system was built, including the addition of a 500-gallon mixing tank, diaphragm pump, and associated valves and piping to connect the mixing tank and sparger tank. Two $3 / 4 \mathrm{hp}$ agitators were added to the mixing tank maximize the potential mixing input available for the 130 Pascal batch runs. Figure 2-2 and Figure 2-3 show the equipment used in the tests. 
WSRC-TR-2004-00488, REVISION 0

SRNL-RPP-2004-00066, REVISION 0

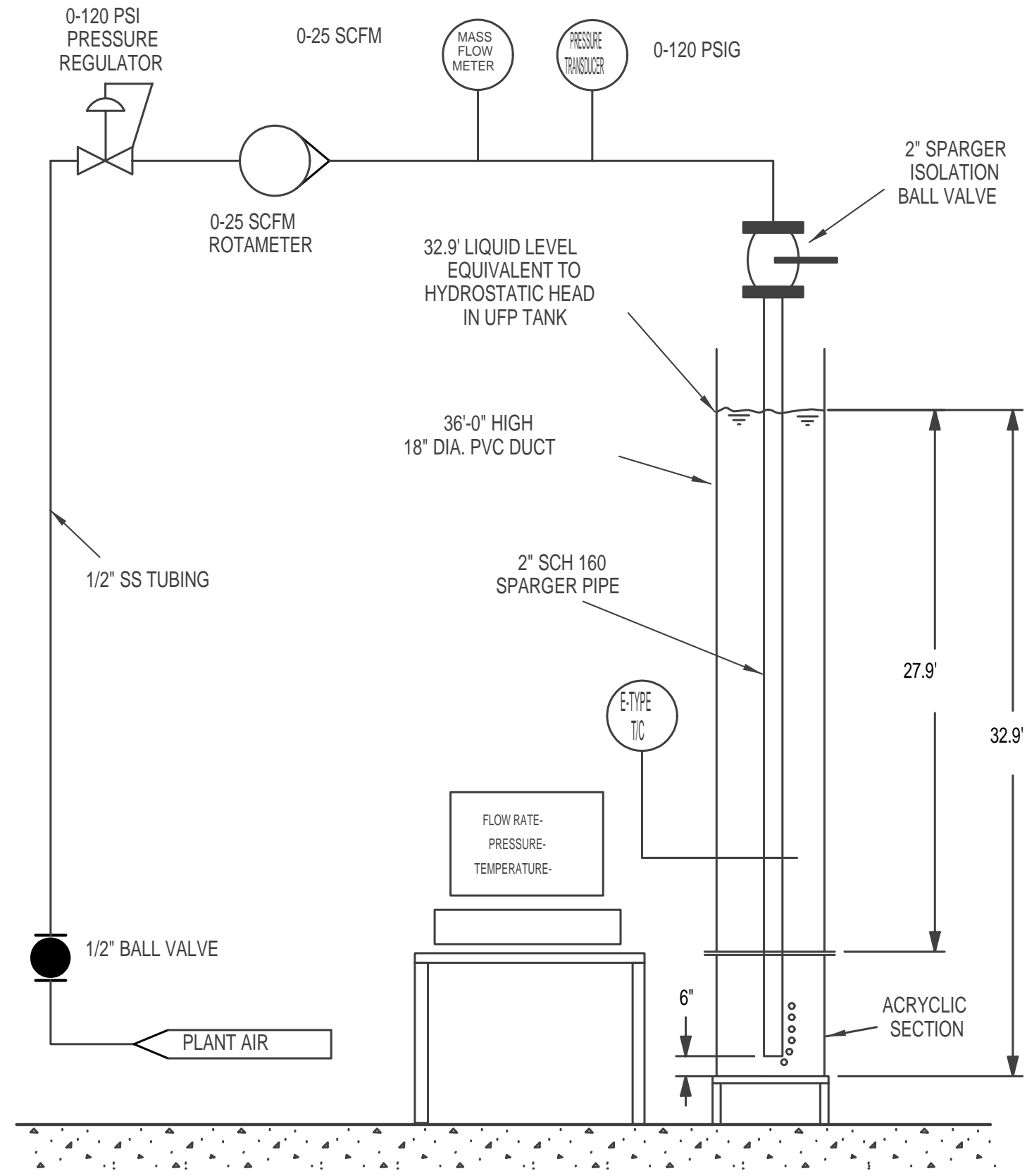

Figure 2-1. Full-Scale Single Sparger Test Loop 
WSRC-TR-2004-00488, REVISION 0 SRNL-RPP-2004-00066, REVISION 0

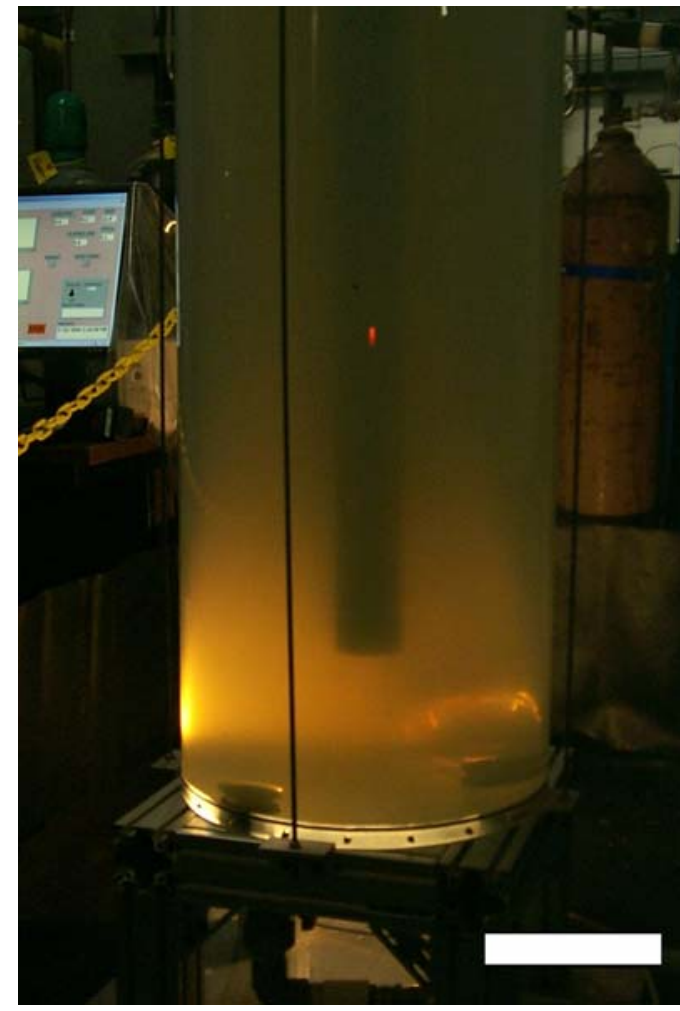

(a) Clear Acrylic Section with Laponite Loaded

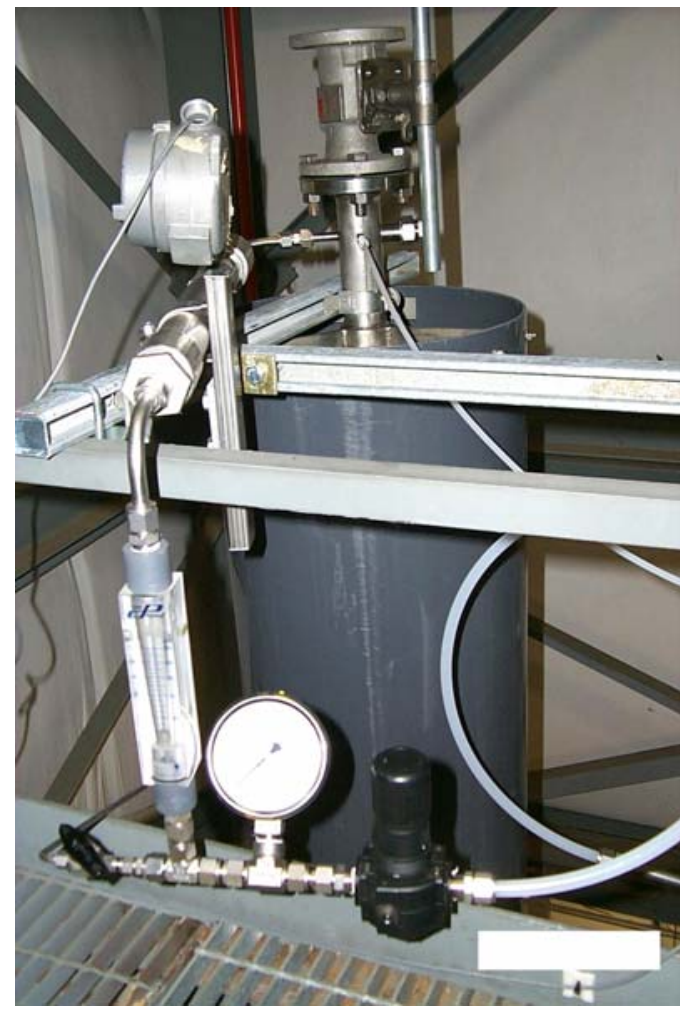

(b) Instrumentation

Figure 2-2. Equipment and Instrumentation

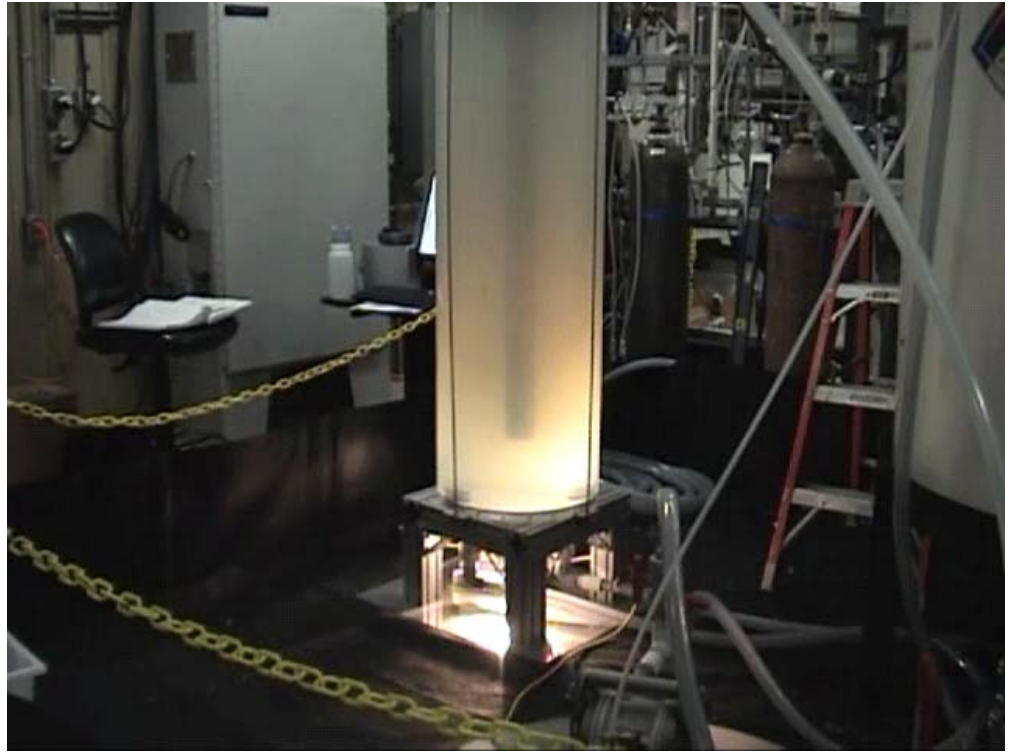

(a) Lower Portion of Test Rig with Laponite Loaded

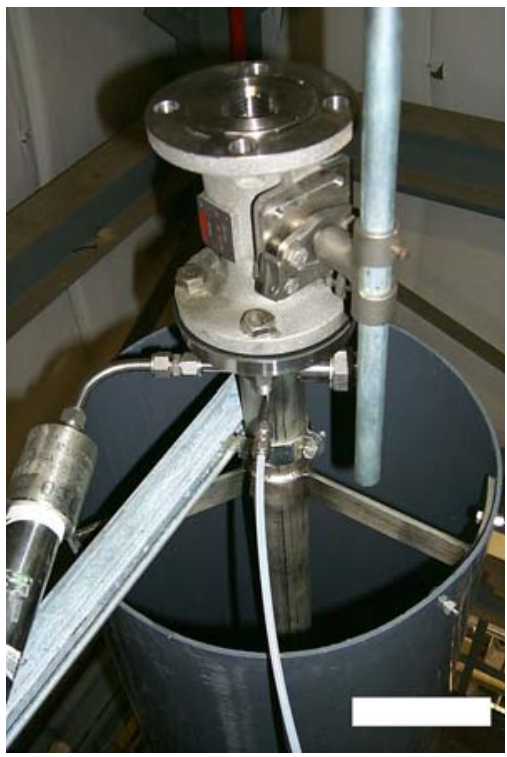

Sparger Isolation Valve

Figure 2-3. Test Rig and Sparger Isolation Valve 


\subsubsection{Test Procedure}

The following procedure was followed:

1) Sufficient quantities ( 430 gallons each )of 120 Pascal Laponite and 30 Pascal Kaolin were produced to fill the test rig

2) The first simulant (Laponite) to be tested was first sheared with a mechanical mixer and samples taken for rheology measurement.

3) The simulant was pumped to the tank to the required fill level and allowed to set for a 24-hour set period.

4) The yield stress of the sample was verified to be the correct value.

5) The Data Acquisition System was started.

6) The two isolation valves were opened and air pressure slowly applied through a regulator valve, starting at 10 psi.

7) The air pressure was increased in 2-psig increments with a 3-minute hold period until breakthrough was detected.

8) The time required to initiate breakthrough after a step pressure increase was noted in the laboratory notebook.

9) After the tank was cleaned, the second test with next simulant (kaolin:bentonite) was initiated, repeating Steps 2 to 8.

To achieve the $120 \mathrm{~Pa}$ Laponite mixture, SRNL developed a recipe based on an existing 65 Pascal Laponite. The recipe called for the $65 \mathrm{~Pa}$ Laponite to be spiked with 0.54 weight percent dry Laponite. The actual measured yield stress after mixing were: $132 \mathrm{~Pa}$ for Laponite and 29.3 Pa for Kaolin:bentonite. The detailed simulant rheology measurements can be found in Sec. 1.6.

\subsubsection{Test Results}

\subsubsection{Test 1 - Laponite}

Test 1 was performed with 430 gallons of a 132 Pascal Laponite/Bentonite mixture. The simulant was loaded into the test vessel in the sheared state and allowed to gel for $24 \mathrm{hrs}$. Based on samples taken during filling the yield stress after 24 hrs was $132 \mathrm{~Pa}$. Air pressure was applied at approximately 7 psig, and incrementally increased in steps of approximately 2 psig. The chart in Figure 2-4 demonstrates the effects of increasing pressure on airflow up to the breakthrough point. The chart includes the calculated hydrostatic pressure at the discharge of the sparger tube, based on the specific gravity of the fluid and the depth into the fluid (32.9').

Upon achieving breakthrough, an immediate fracturing of the Laponite occurred, similar to the crack propagation evident in large chunks of ice under tensile loading. It was observed that once the air bubbles rising in the tank developed a fracture path to the surface, this fracture path was maintained fairly consistently for 10-20 seconds, the air jumping from fracture path to fracture path in a random pattern. 
It appears that with each step increase in pressure, the Laponite in the sparger tube dropped in elevation after a short period of air inflow, followed by pressure stabilization. This continued until the air reached the discharge of the sparger tube, and the pressure and flow stabilized. This was verified through measurements of the main tank level changes. Each stepped pressure increase raised the main tank level. At 10 psi, the tank height was 34” from the lip to the surface. At 12 psi, the tank height to the surface was $33 \frac{1 / 4}{4}$. And just prior to breakthrough, at a pressure of 14.6 psi, the tank height was measured to be 32 9/16”. These measurements were later mathematically related with sparger tube heights, and indicated that the decrease in level inside the sparger (from the bottom) corresponded with the increase in tank level, and that the decrease in level in the sparger was inversely proportional to the air pressure applied (once stabilized).

Once breakthrough was achieved, the air pressure became fairly stable. The variation in the airflow and pressure can probably be attributed to the changes in backpressure as the air bubbling up stream through the Laponite jumped from fracture path to fracture path. A picture of a typical fracture path just after break through is shown in Figure 2-5.

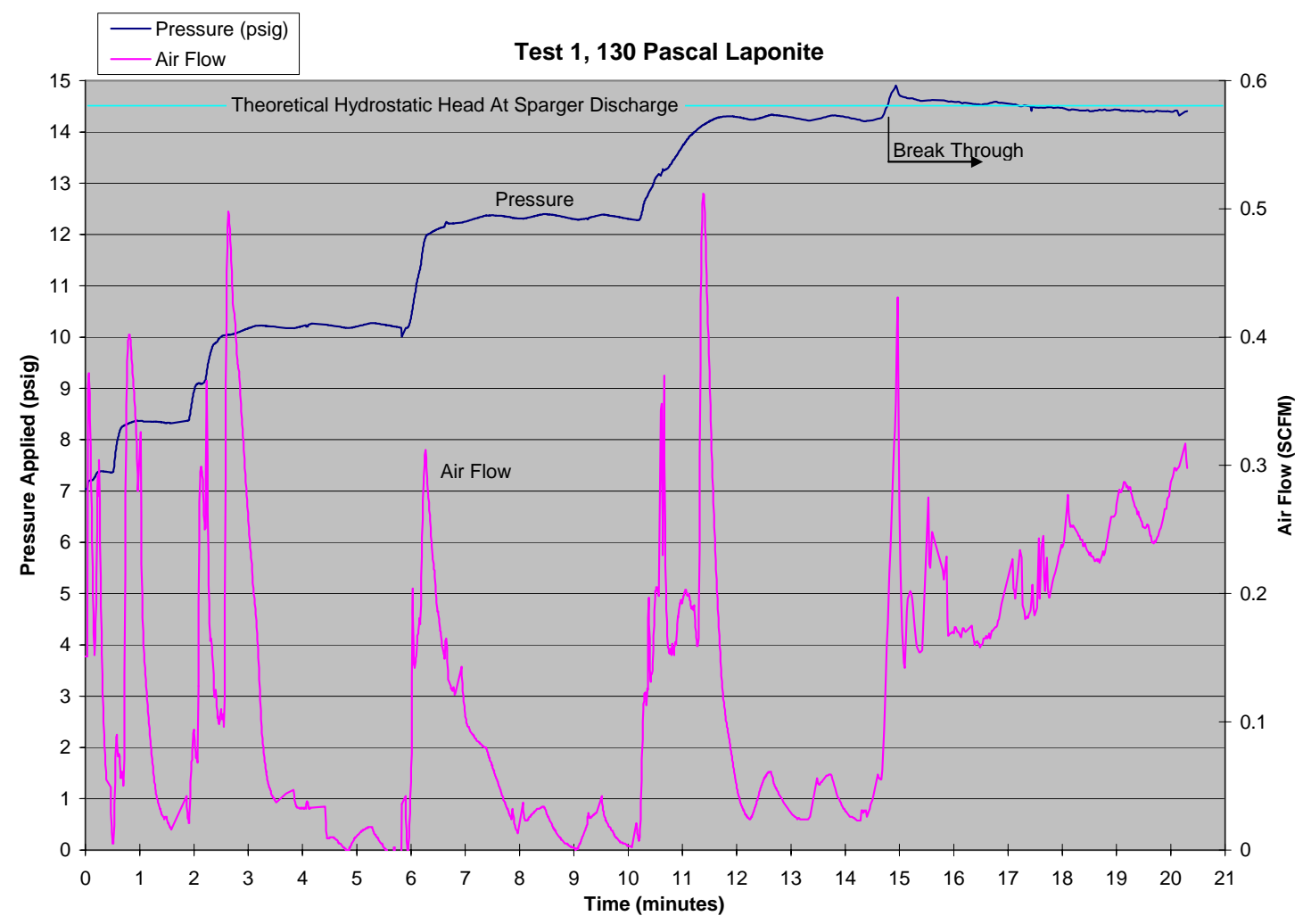

Figure 2-4. Test 1 Full-Scale Sparger Test Results with 132.2 Pa Y.S. Laponite 


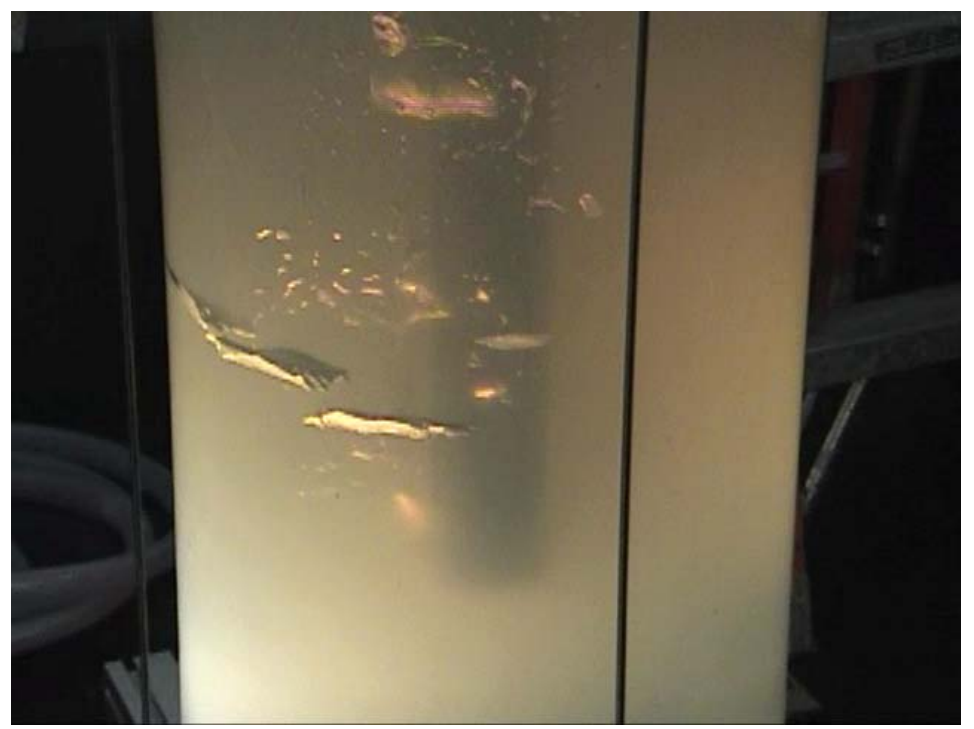

Figure 2-5. Crack Propagation During Sparger Testing in Laponite

\subsubsection{Test 2 - Laponite}

Test 2 was performed the following day after Test 1, and again was performed with 132 Pascal Laponite. After breakthrough, the principal investigator was asked to continue increasing airflow to determine the sparging effects on the laponite. Figure 2-6 shows the airflow and pressure up to breakthrough, and Figure 2-7 shows the complete airflow and pressure, including the follow-up sparging testing.

The breakthrough portion of Test 2 was identical to that of Test 1 , and verified the overall dynamics of the UFP Sparger with 132 Pascal material shown in Test 1. Both Tests 1 and 2 are essentially identical in system dynamics. Again, once breakthrough was achieved, the air pressure and flow achieved a relative stability, with the pulsing of the airflow shown most likely resulting from changes in fracture paths being followed by the escaping air.

A follow-up of Test 2 included increasing the airflow in steps and observing the effects of sparging on the laponite. Figure 2-6 and Figure 2-7 show the full data from this test run, including breakthrough and airflow variations after breakthrough. 
WSRC-TR-2004-00488, REVISION 0

SRNL-RPP-2004-00066, REVISION 0

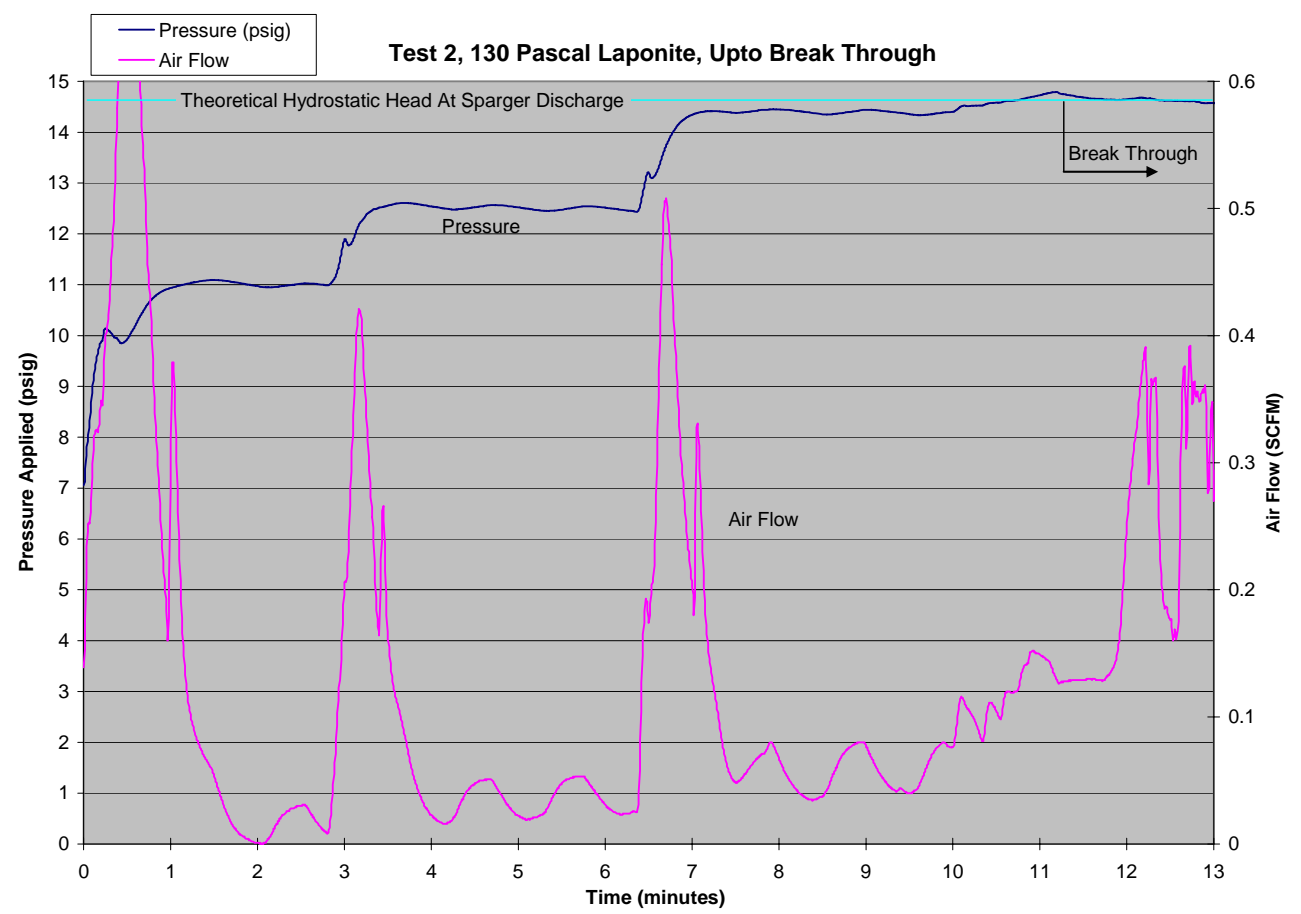

Figure 2-6. Test 2 - 132 Pascal Laponite/Bentonite, Run till Breakthrough

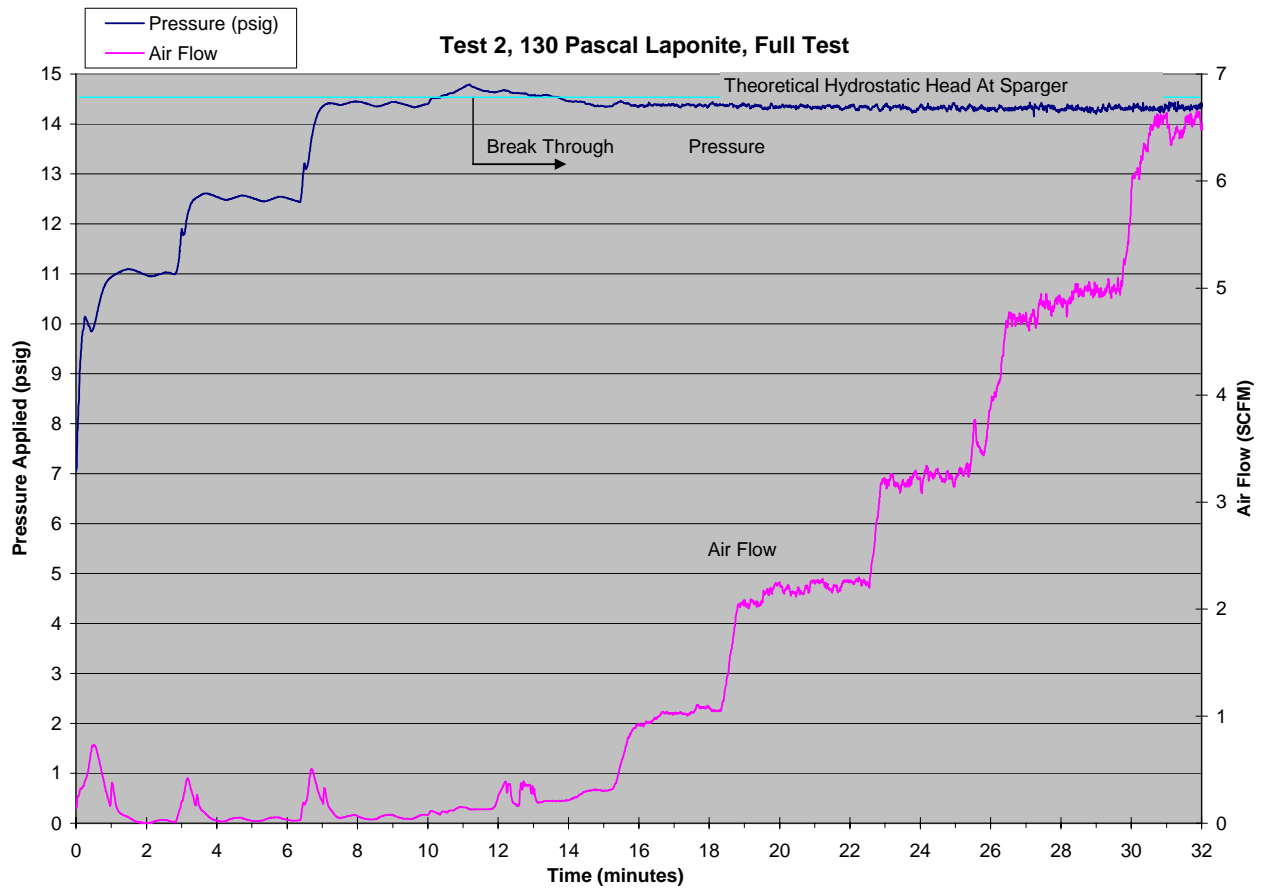

Figure 2-7. Test 2 - 132 Pascal Laponite/Bentonite, Run including Sparging Studies 
Once breakthrough was established, the airflow was increased to $1 \mathrm{scfm}$ and held for approximately 3 minutes. At this flow rate, the airflow began to assume the typical sparger upflow pattern, bypassing any previous fracture paths for a more direct path to the surface. The bubbles were observed to increase in size from the breakthrough airflow. A picture of the sparging at $1 \mathrm{scfm}$ is shown in Figure 2-8.

The flow was increased to $2 \mathrm{scfm}$, and was maintained for approximately 4 minutes. A single sparging path was again observed, but the tip of the sparger was noticed to be liquefied. The bubbles were observed to be approximately 2" to 3" in size. Bulk movement of the outer diameter laponite was observed slowly ( 2"/min) migrating downwards in the acrylic section. Recirculating flow is observed to be just starting. A picture of the sparging at $2 \mathrm{scfm}$ is provided in Figure 2-9.

The flow was then increased to $5 \mathrm{scfm}$, and maintained for approximately 4 minutes. It was observed that a 3" to 4" column was being swept up in the visible section of the test rig (the bottom 5 feet). This is depicted schematically in Figure 2-10. The visible section of Laponite was determined to be fluidized. The bulk movement of the outer flow of material was observed to be moving downwards at $\sim 10$ ”/min. The inner column was observed to be moving upwards, but a bulk movement speed was not discernable. A picture of the sparging at $5 \mathrm{scfm}$ is shown in Figure 2-11.

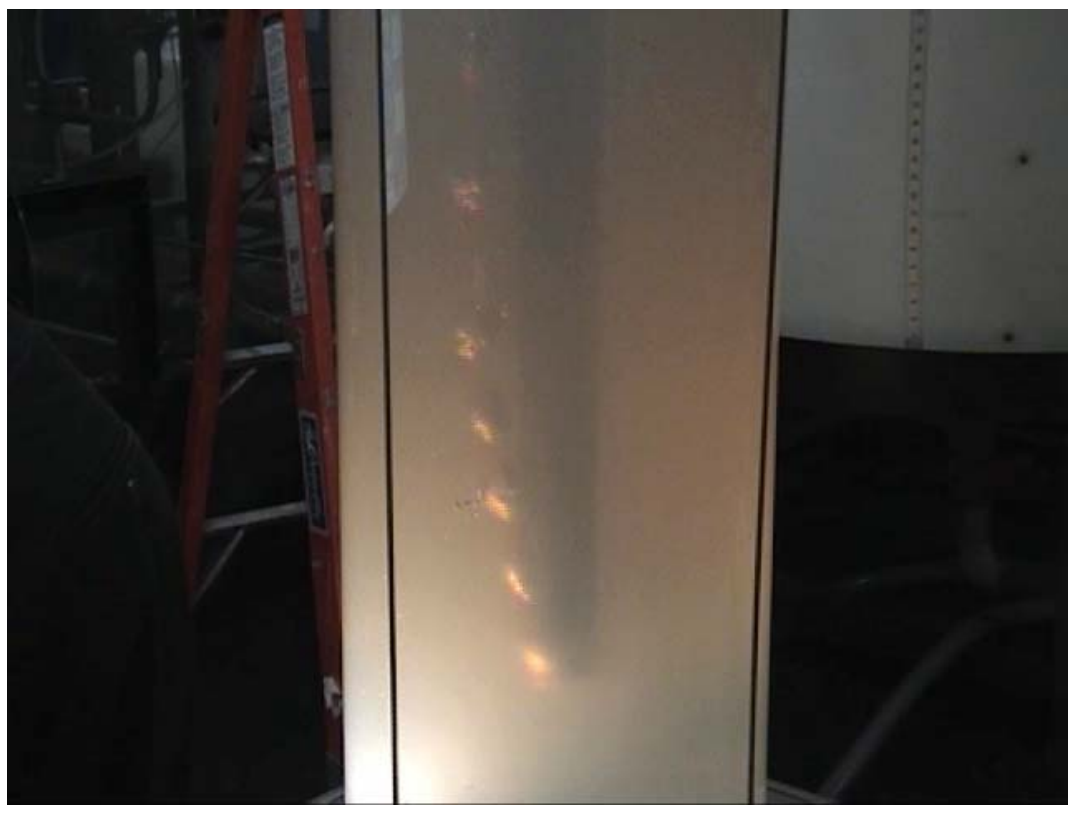

Figure 2-8. Sparging at 1 SCFM 


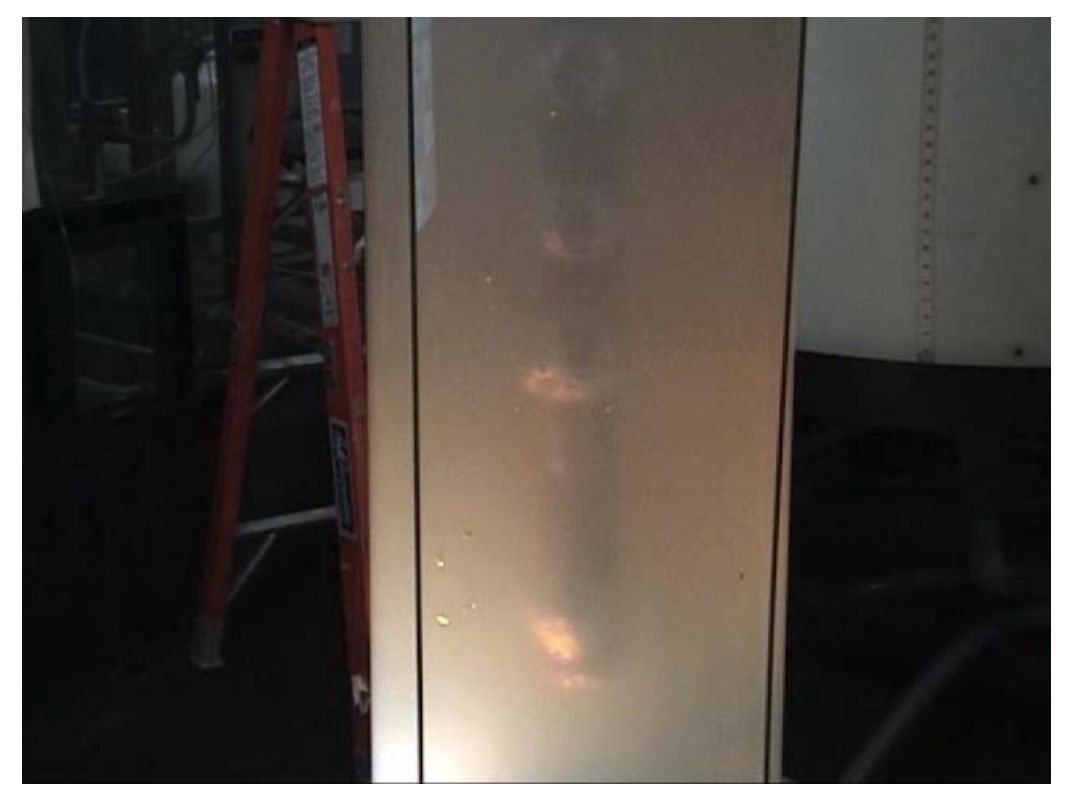

Figure 2-9. Sparging at 2 SCFM

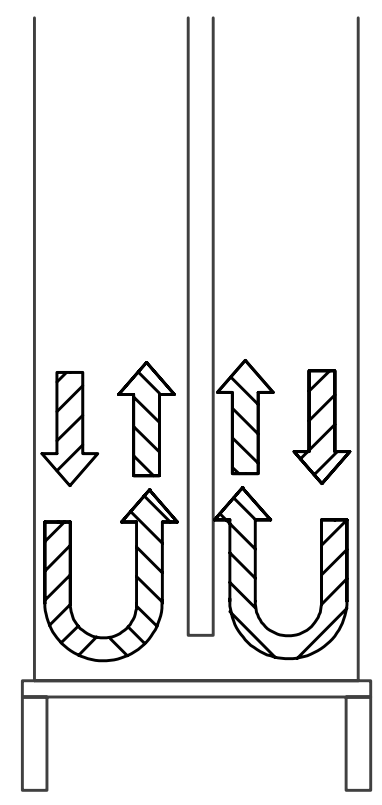

Figure 2-10. Schematic Diagram Illustrating Bulk Movement of Laponite during Sparging 


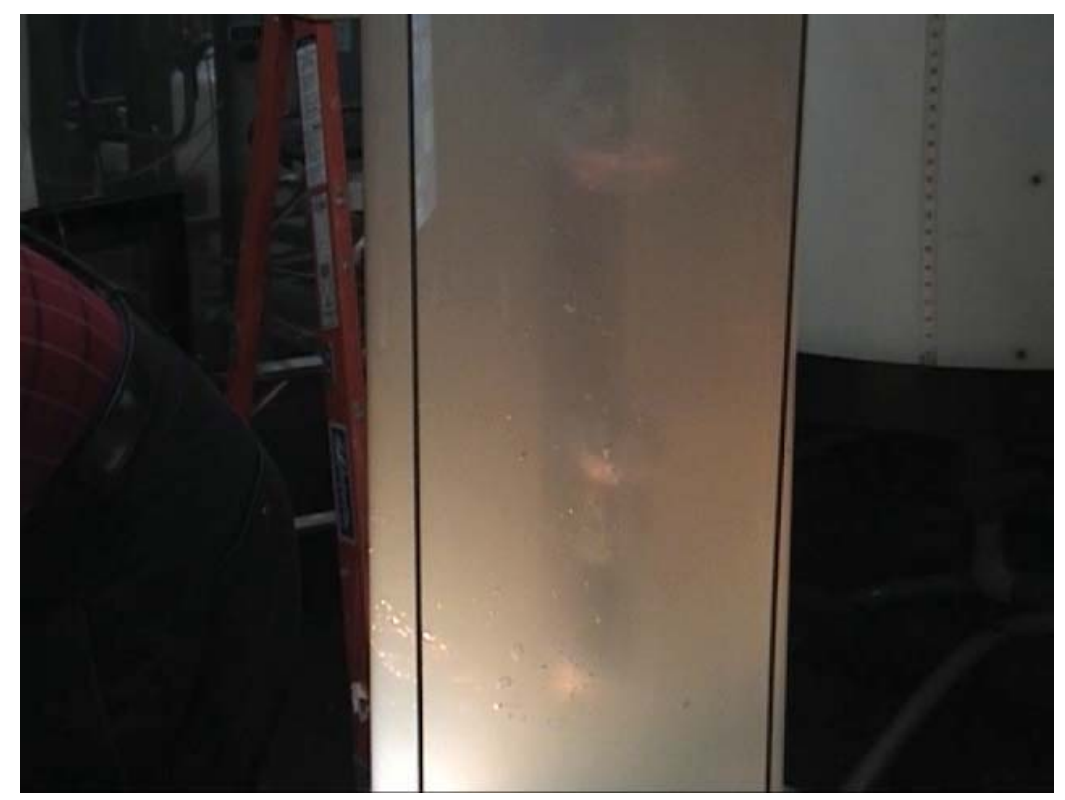

Figure 2-11. Sparging at 5 SCFM

The airflow was bumped up to $6.5 \mathrm{scfm}$, with no noticeable difference in liquefaction of the Laponite. The bubbles again grew in size, and were estimated to be approximately 8 " in diameter. Bulk fluid movement was estimated to be 20"/min down the outside of the acrylic section. No mixing below approximately $1 / 2$ " from the bottom of the sparger tube was observed. A picture of the sparging at $6.5 \mathrm{scfm}$ is shown in Figure 2-12.

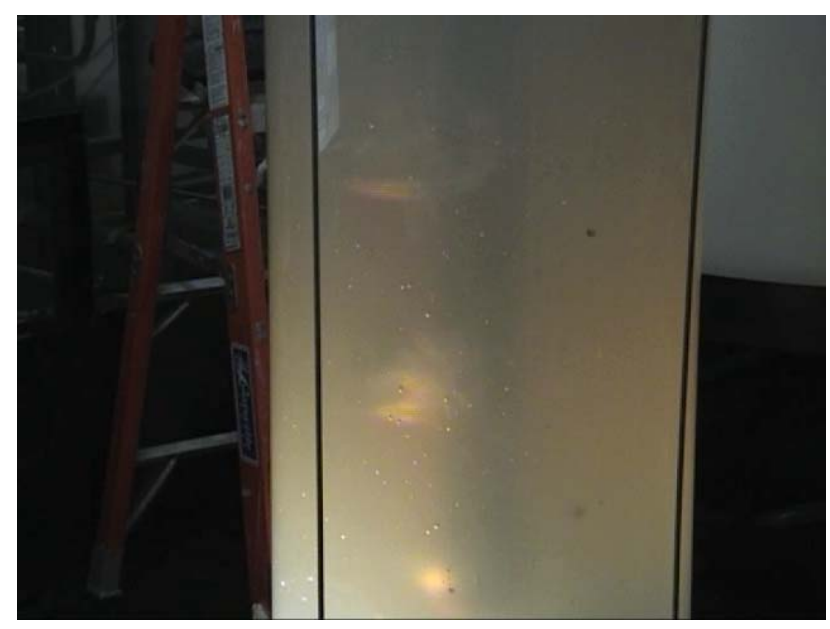

Figure 2-12. Sparging at 6.5 SCFM 
Observations were made at the surface of the laponite. The initial surface penetration of bubbles occurred at one location, and then breached the surface at two separate locations, while the air flow was maintained at the breakthrough air flow rate. This appears to be the result of the air jumping from fracture path to fracture path. At $0.7 \mathrm{scfm}$, the surface became breached at one location, with vibrational waves propagating outward from the breach point. When 2 scfm was achieved, the complete surface was fluidized.

\subsubsection{Test 3 - Kaolin}

The third test was run with 30 Pascal, 30 centipoise Kaolin:bentonite clay. The results are shown in Figure 2-13. Several differences were noted between the Laponite testing and the Kaolin testing. Because of the higher specific gravity of the Kaolin (s.g.-1.18), the hydrostatic pressure increased at the sparger tip, and a greater air pressure was required to clear the sparger. Of interest was the significantly greater airflow maintained once breakthrough occurred. An airflow of $0.3 \mathrm{scfm}$ at a pressure of $14.7 \mathrm{psig}$ of was required for 132 Pascal Laponite to clear the tube versus $1.6 \mathrm{scfm}$ at 1.67 psig for 30 Pascal Kaolin. This is approximately a 5-fold increase in air required to maintain the cleared condition.

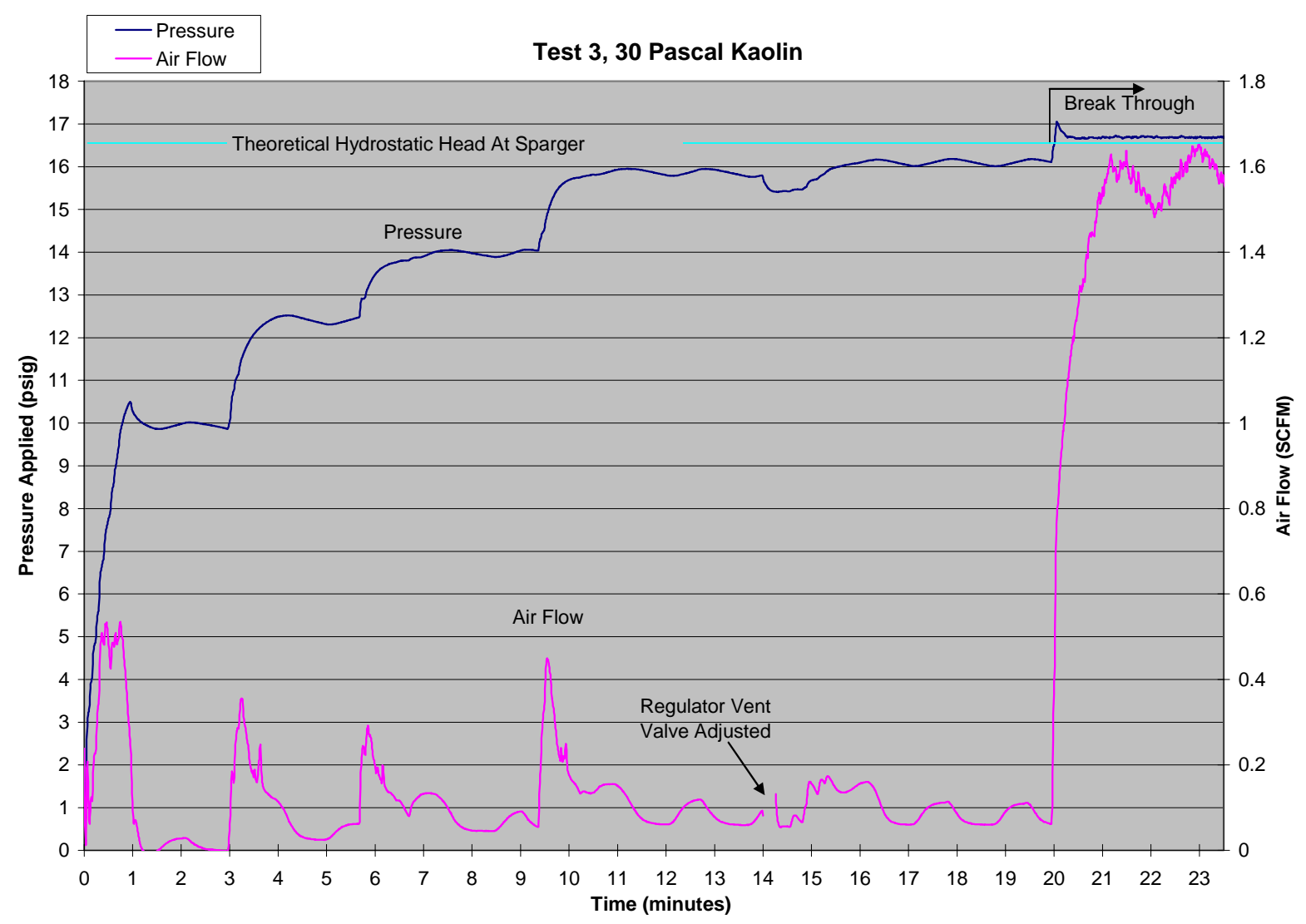

Figure 2-13. Test 3 - 30 Pascal Kaolin, Run till Breakthrough 


\subsubsection{Conclusions}

The air pressure required to clear the sparger correlated very closely with the calculated hydrostatic pressure at the sparger tip. The theoretical pressures required to overcome hydrostatic head were calculated as 14.7 psig and 16.3 psig for the Laponite and Kaolin, respectively. The actual pressures measured to overcome hydrostatic head were 14.7 psig and 16.7 psig for the Laponite and Kaolin, respectively.

This result, where breakthrough occurs very closely to the calculated static head of the simulant column inside the sparger, implies, especially for Laponite which has a definite yield stress, that yield stress does not have an effect on breakthrough. Based on a force balance between the air acting on the pipe cross-sectional area, the static pressure at the bottom of the sparger, and the Laponite shear stress (120 Pa) acting on the sparger inside pipe area, the excess air pressure over the hydrostatic head should be an additional 15.4 psig. Any excess pressure developed was not transmitted instantaneously over the total sparger inside pipe area, but was probably acting locally where the air pressure was applied. This could have caused local yielding or fracturing, which could have propagated down the pipe. With the clay simulant, there was zero yield stress at close to zero strain rate, and therefore, the simulant could flow with very little excess air pressure.

It appears from observations that the Laponite column in the sparger did not flush out abruptly, but was slowly expelled from the tip of the sparger with increasing pressure. Once breakthrough was achieved in the Laponite, the initial sparging pattern was adherence of the air to a fracture path to the surface. Once the air flow was increase to at least $1 \mathrm{scfm}$, actual fluidization began, starting with a conical section surrounding the sparger and working its boundary outward with increasing air flow.

Kaolin testing revealed that the air flow maintained, once initial break through was achieved, was substantially greater than the Laponite. This is attributed to the fact that the Kaolin is fluidized during testing, and hence requires greater air flow to maintain sparging. The Laponite developed fracture paths immediately, providing reduced backpressure once initial breakthrough was achieved.

\subsection{UFP RESTART TESTING}

\subsubsection{Objective}

The overall objective of the test was to determine if the PJMs in WTP vessels with nonNewtonian waste having a yield stress of $600 \mathrm{~Pa}(+/-25 \mathrm{~Pa})$ can be restarted by normal operation of PJMs only, or what air sparging flow is necessary to assist the PJMs restart. The required PJM air pressure and sparger air flows for restart were measured. A 1/4 scale model of the UFP with a height-to-diameter (H/D) ratio of 1.42 was used for the demonstration. 


\subsubsection{Test Apparatus}

The test stand employed in Concentrate Receipt Vessel (CRV) PJM testing was used to simulate the UFP vessel. The CRV vessel has the same tank diameter and height as the UFP at Battelle. It also has a similar chandelier arrangement of (6) 8-inch diameter PJMs. The only required modification was removal of the CRV charge vessels and installation of (5) $45^{\circ}$ downward nozzles and (1) downward center nozzle, all 1 inch in diameter. The 5 sparger lines were 0.37 inch I.D. Figure 2-14 is a picture of the test stand while Figure 2-15 is a line drawing of the test vessel with PJMs.

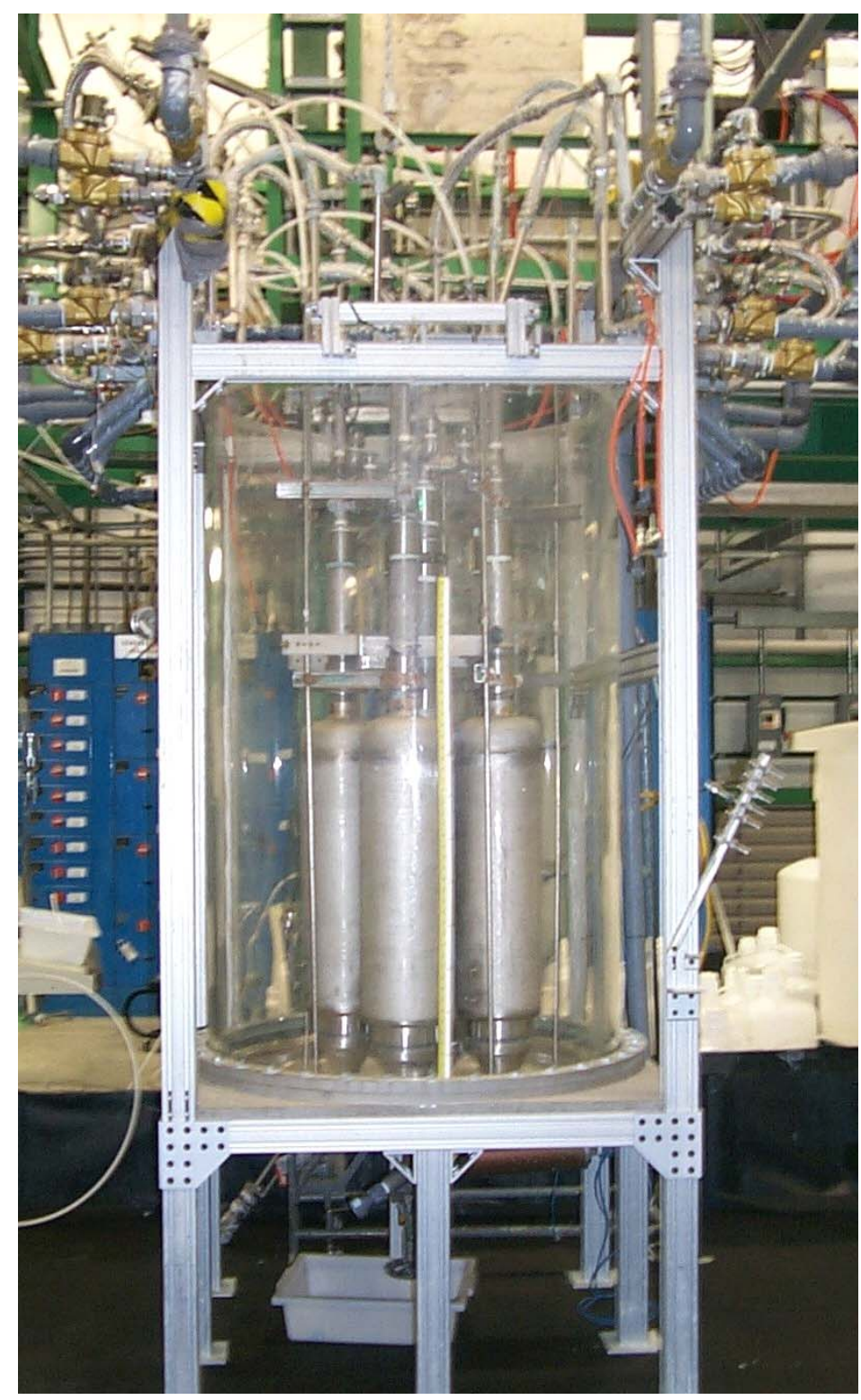

Figure 2-14. Test Stand Used in UFP Restart Testing 
WSRC-TR-2004-00488, REVISION 0

SRNL-RPP-2004-00066, REVISION 0

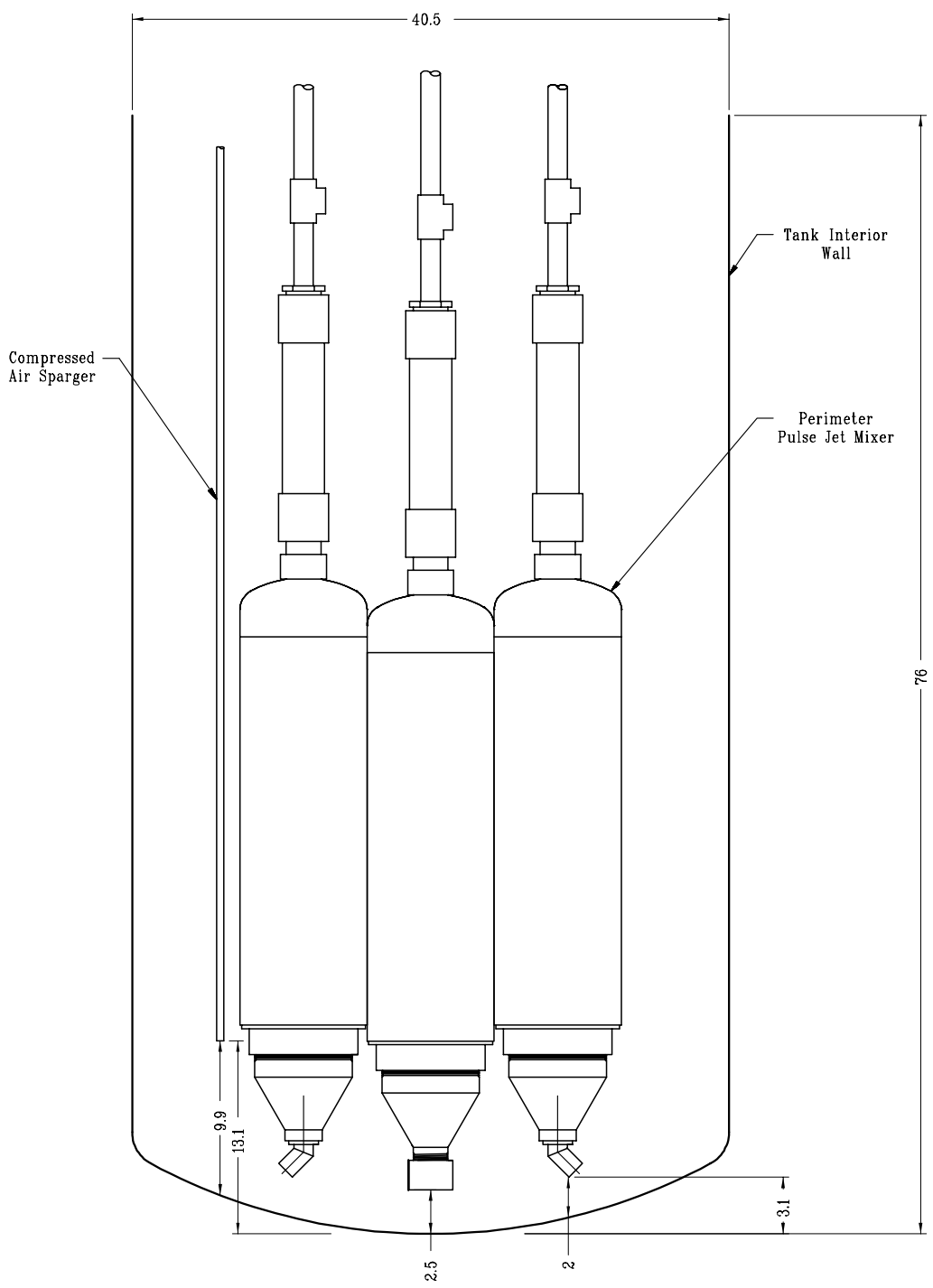

Figure 2-15. Elevation View of UFP Restart Test Vessel 


\subsubsection{Test Procedure}

The kaolin:bentonite mixture was first mixed as described in Sec. 1.6.2. As soon as the clay/laponite mixture showed no fish eyes during the mixing process (typically one hour of mixing), it was pumped into the test vessel, since it started to show significant thickening. The PJM air pressure, drive time, cycle time, and trip levels were determined by preliminary pulsing prior to the 24-hr. wait. The cycle time for full travel of the PJMs (fully liquefied simulant) was 35 seconds, compared to $20-25$ seconds for $30 \mathrm{~Pa} / 30 \mathrm{cP}$ simulant, due to the long refill time. During calibration of the level probes, which required a few pulsing steps, it was evident that refilling the PJMs was getting more difficult as time went on and with the available suction pressure. This was probably due to higher consistency of the simulant or more extensive gelling. The average PJM fill level was 39.2” prior to the 24-hr. gel time period, while the clay was still in the fully sheared condition.

The restart test was conducted by operating only the PJMs for 10 to 20 cycles manually at the same PJM air pressure used during the calibration test. The initial drive distance was 27”. A period of stable automatic operation was then conducted. Then the 5 air spargers were turned on at 5, 7, and $10 \mathrm{scfm}$ total air flow rates at 10 to 20 cycles each, and determining what PJM travel can be supported as more and more of the simulant was fully sheared.

\subsubsection{Test Results}

\subsubsection{475 Pa Simulant}

A summary of the test conditions, including yield stress, tank H/D ratio, nozzle velocity, and initial PJM level for the $475 \mathrm{~Pa}$ clay test is given in Table 2-1. Although the tank level was 55”, the initial PJM level was only 39” with the vents open. The high consistency of the simulant prevented equalization of the level, even with the vacuum on. In Table 2-2, the number of cycles at each test condition, e.g., PJM only, PJM + 7 scfm air sparging, etc., are tabulated together with the drive distance and maximum PJM pressure. The results for number of cycles and drive distance are also plotted in Figure 2-16.

Table 2-1. UFP Restart Test 1 Conditions

\begin{tabular}{|l|c|}
\hline Kaolin/Laponite Yield Stress, Pa & 475 \\
\hline UFP H/D $=$ & 1 \\
\hline Average initial PJM level & $39 "$ \\
\hline Target PJM drive distance & $27 ”$ \\
\hline Nozzle velocity & $12 \mathrm{mps}$ \\
\hline
\end{tabular}


WSRC-TR-2004-00488, REVISION 0

SRNL-RPP-2004-00066, REVISION 0

Table 2-2. UFP Restart Test 1 Results

\begin{tabular}{|l|c|c|c|c|}
\hline $\begin{array}{l}\text { PJM/Sparging } \\
\text { Conditions }\end{array}$ & $\begin{array}{c}\text { Number of } \\
\text { cycles }\end{array}$ & $\begin{array}{c}\text { Cumulative } \\
\text { cycles }\end{array}$ & $\begin{array}{c}\text { PJM drive } \\
\text { distance, in. }\end{array}$ & $\begin{array}{c}\text { PJM max. } \\
\text { press., psig }\end{array}$ \\
\hline PJM only (manual) & 16 & 19 & 9.2 & 11.2 \\
\hline PJM only (automatic) & 76 & 95 & 12.7 & 10.9 \\
\hline PJM + 5 scfm & 10 & 105 & 16.5 & 12.9 \\
\hline PJM + 7 scfm & 20 & 125 & 17.3 & 13.1 \\
\hline PJM + 10 scfm & 16 & 141 & 17.3 & 13.1 \\
\hline
\end{tabular}

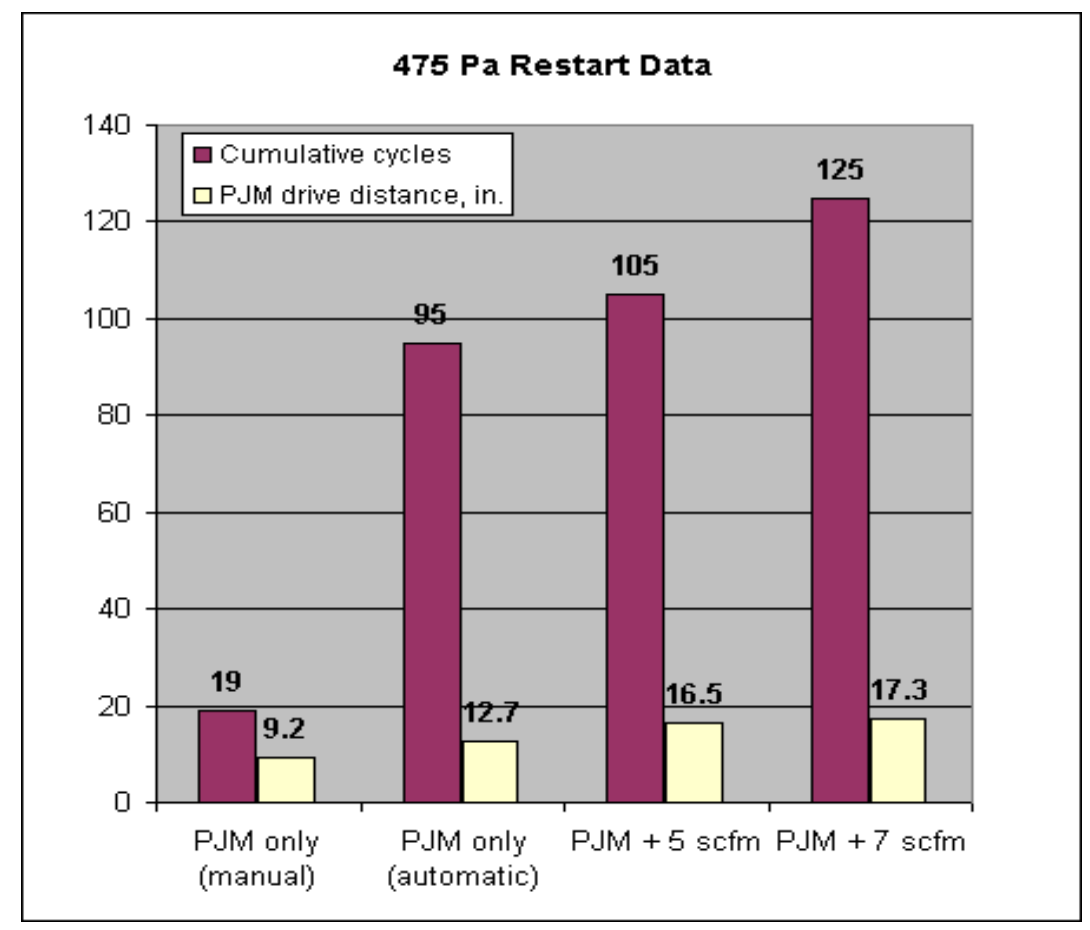

Figure 2-16. Test 1 Cumulative Cycles Required for UFP Restart and PJM Drive Distance

\subsubsection{596Pa Simulant Test}

For the 596Pa simulant, the test conditions, including yield stress, tank H/D ratio, nozzle velocity, and initial PJM level are given in Table 2-3. In Table 2-4, the number of cycles at each test condition, e.g., PJM only, PJM + 7 scfm air sparging, etc., are tabulated together with the drive distance and maximum PJM pressure. The results for number of cycles and drive distance are also plotted in Figure 2-17. 
Table 2-3. UFP Restart Test 2 Conditions

\begin{tabular}{|l|l|}
\hline Kaolin/Laponite Yield Stress, Pa & 596.5 \\
\hline UFP H/D = & 1.375 \\
\hline Average initial PJM level & $39 "$ \\
\hline Target PJM drive distance & $27 ”$ \\
\hline Nozzle velocity & $12 \mathrm{mps}$ \\
\hline
\end{tabular}

Table 2-4. UFP Restart Test 2 Results

\begin{tabular}{|l|c|c|c|c|}
\hline $\begin{array}{l}\text { PJM/Sparging } \\
\text { Conditions }\end{array}$ & $\begin{array}{c}\text { Number of } \\
\text { cycles }\end{array}$ & $\begin{array}{c}\text { Cumulative } \\
\text { cycles }\end{array}$ & $\begin{array}{c}\text { PJM drive } \\
\text { distance, in. }\end{array}$ & $\begin{array}{c}\text { PJM max. } \\
\text { press., psig }\end{array}$ \\
\hline PJM only (manual) & 16 & 19 & 9.2 & 11.2 \\
\hline PJM only (automatic) & 76 & 95 & 12.7 & 10.9 \\
\hline PJM + 5 scfm & 10 & 105 & 16.5 & 12.9 \\
\hline PJM + 7 scfm & 20 & 125 & 17.3 & 13.1 \\
\hline PJM + 10 scfm & 16 & 141 & 17.3 & 13.1 \\
\hline
\end{tabular}

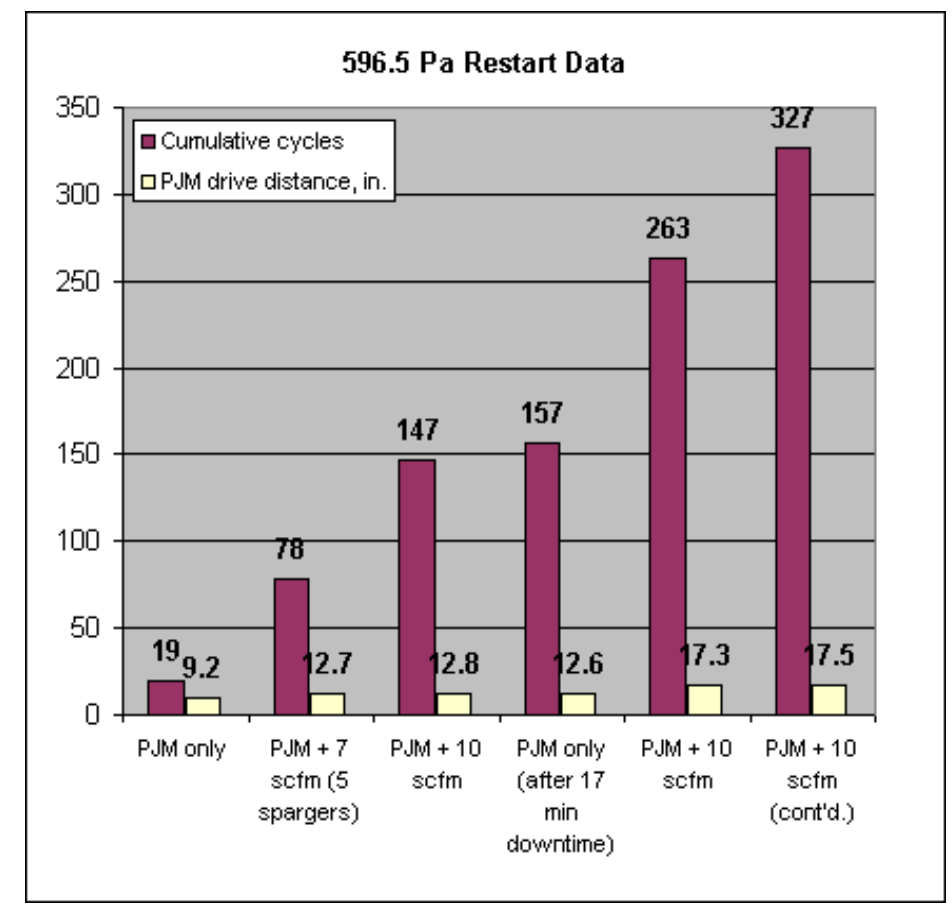

Figure 2-17. Test 2 Cumulative Cycles and PJM Drive Distance Required for UFP Restart 
Observation - during the initial drive phase, starting from the full PJM level, application of the same PJM air pressure during normal operation does push the jelled simulant the full travel distance, but on the refill or suction phase, the maximum simulant height in the PJM was less than half of the original travel.

For the 475 Pa simulant, the initial drive distance with PJM only operation was 9.2 inches. This increased to a final drive distance of 17.3 inches, in stepwise fashion as the number of cycles accumulated to a total of 147 cycles, and as the air sparger increased from 5, 7, and 10 scfm. The maximum air pressure inside the PJM increased slightly from 11.2 psig to 13.1 psig.

For the 596Pa simulant, the results were similar, but it took more cycles (263 cycles) to reach the same final drive distance (17.3 inches) as with the $475 \mathrm{~Pa}$ simulant. This final drive distance appeared to be stable with additional cycles (327 total accumulated cycles). The maximum PJM air pressure hardly changed from the initial value of 13.1 psig. Figure 2-18a shows the surface of the 600 Pa clay during sparging operation.

The addition of sparging did increase the PJM drive distance, but not significantly. This is due to the limited zone of influence of the air bubbles, since a channeling effect occurs as a vent hole is created adjacent to each sparger (Figure 2-18b). The same thing could happen in the plant, since the air bubbles would tend to follow the path of least resistance along the vent hole. Increasing the air flow 42\% (7-10 scfm) increased the drive distance also 40\% (12.5”17.5 ”), but only $14 \%$ of the normal drive distance. This could be due to the high consistency of the simulant and may not be true of the real waste.

Looking through the transparent tank wall, it was apparent that a liquid film was formed along the wall; but air bubbles along the tank wall showed a solid-gelled plug moving up and down during the pulsing (Figure 2-19). A cavern was not visible above the bottom flange. Again this could be an artifact of the simulant used, which had a higher consistency than the real waste.

\subsubsection{Conclusions}

Based on the results of these tests, it may be concluded that a simulant with a yield stress of $600 \mathrm{~Pa}$ can be restarted even with PJM operation only. Addition of air sparging does improve the shearing of the simulant, but not significantly. This was due to the creation of vent holes, limiting the zone of influence of bubbles. What limits the drive distance or the cavern size is the apparently high consistency of the simulant, as evidenced by the shorter refill height. Since the $30 \mathrm{~Pa}$ Y.S. and $30 \mathrm{cP}$ simulant requirement for flowing conditions was not achieved, these results are conservative. Better results would probably be obtained with the real waste which has a lower consistency than the simulant. Tests with the proper simulant having a $30 \mathrm{~Pa} / 30 \mathrm{cP}$ characteristics would probably achieve the full travel. 
WSRC-TR-2004-00488, REVISION 0 SRNL-RPP-2004-00066, REVISION 0

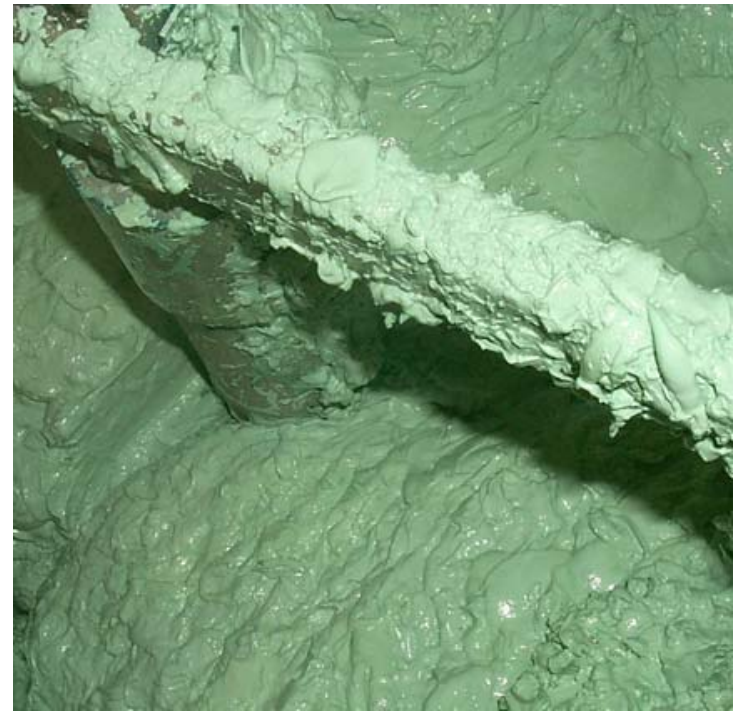

(a) Top Surface of during Pulsing

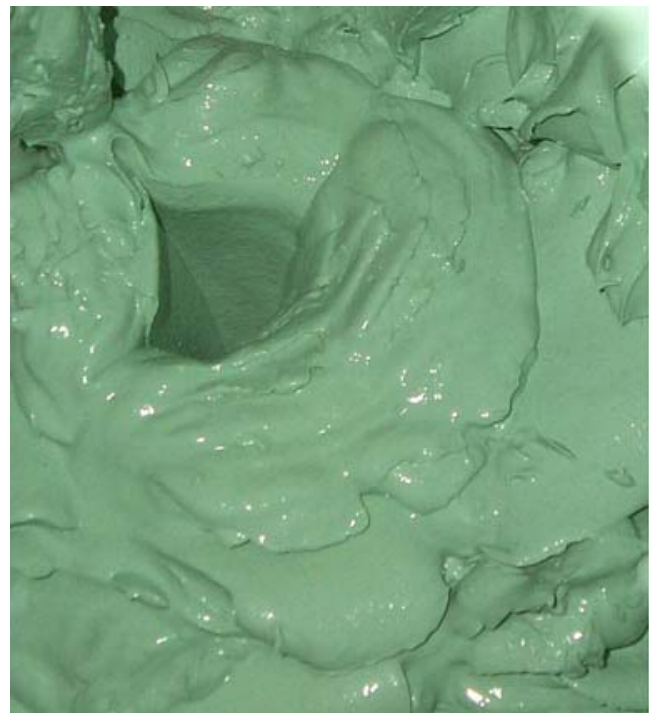

(b) Vent Hole during Air Sparging

Figure 2-18. Tests with 600 Pa Clay

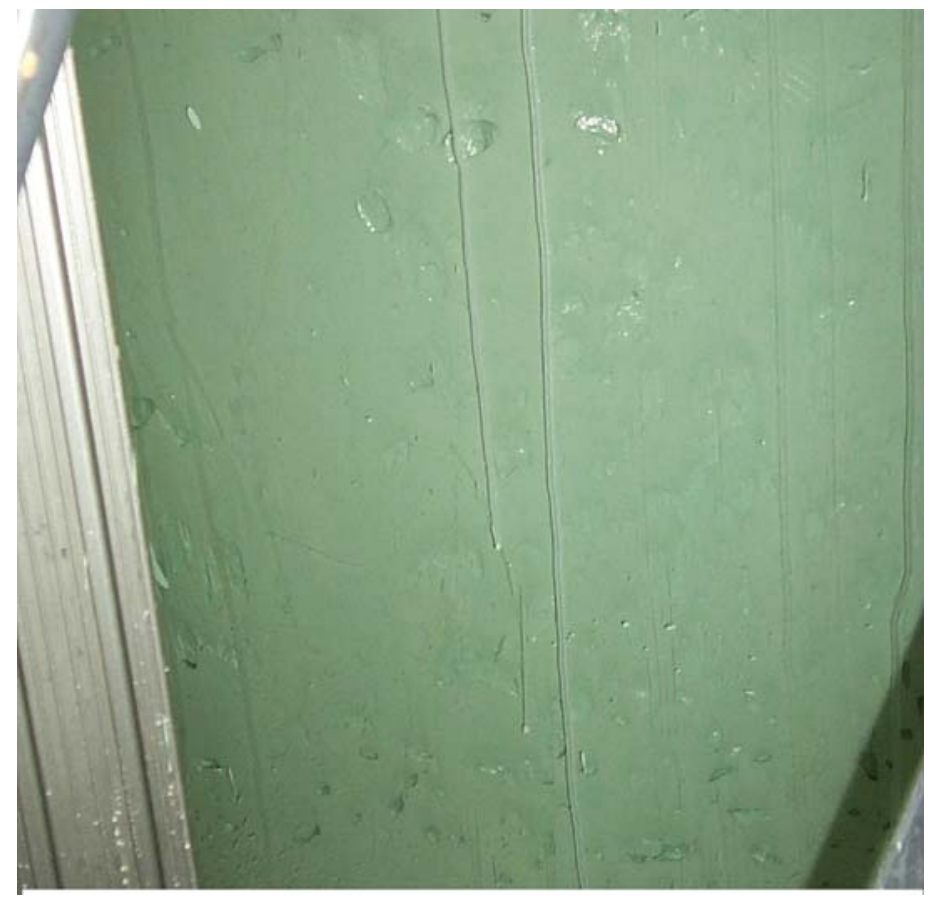

Figure 2-19. Bubbles along Tank Wall Showing Jelled Simulant during Pulsing (600 Pa) 


\subsection{UFP GLASS BEADS TESTING}

\subsubsection{Objective}

The objective of this testing was to determine the air flow required and height off the bottom necessary to cause $5 \mathrm{~mm}$ glass beads to be lifted off the tank bottom. All testing was performed using process water. All testing began with the pipe end located 6" off the bottom of the tank, and progressively moved closer to the bottom to ascertain the effect of height on bead lift.

\subsubsection{Test Apparatus}

The test stand employed in Concentrate Receipt Vessel (CRV) PJM testing (located in 786-A/Savannah River National Laboratory) was used for this test. Process water was loaded into the tank to a level of 40 ”, giving a height to diameter ratio of 1.0. The initial height from the bottom was set at 6”, and was lowered during testing to determine the effects of height on glass bead movement.

The two types of sparger bottoms are shown in Figure 2-20a and Figure 2-20b. Both spargers were made from 2” Sch 160 stainless steel pipe.

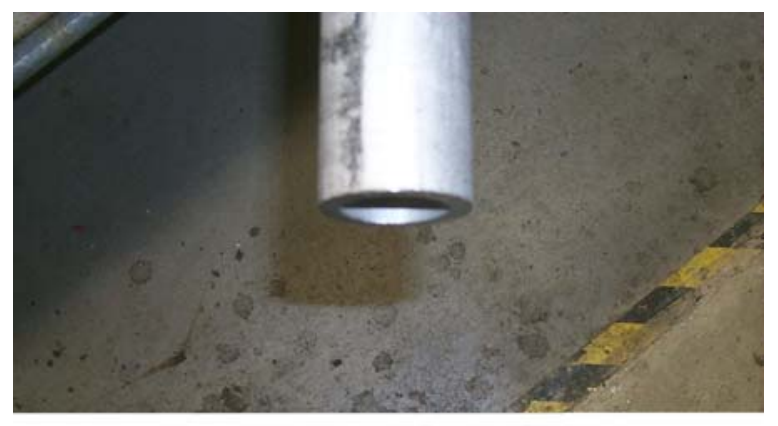

(a) Flat End

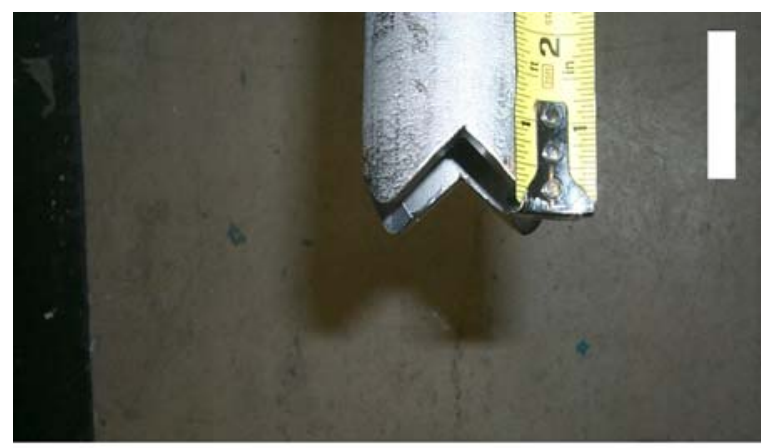

(b) $45^{\circ}$ Notched End

Figure 2-20. Sparger Bottoms Used in UFP Glass Beads Test

\subsubsection{Test Procedure}

The procedure used in conducting the test basically consisted of the following steps:

1. Add water to appropriate height in the CRV tank.

2. Add approximately $5 \mathrm{~kg}$ of $5 \mathrm{~mm}$ glass beads (enough to cover tank bottom to a 1-bead-thick layer of beads).

3. Set height of sparger to 6" off of tank bottom.

4. Begin flowing air at $10 \mathrm{scfm}$, and document observations.

5. Increase air flow in $10 \mathrm{scfm}$ increments, to a maximum of $50 \mathrm{scfm}$, documenting observations at each step.

6. Replace Flat Tip Sparger with Notched Sparger and repeat. 


\subsubsection{Test Results}

The data is summarized in Table 2-5 for the Flat-faced Nozzle and in Table 2-6 for the Notched-faced Nozzle.

Table 2-5 shows that for the flat-faced sparger, no movement of the glass beads was observed until the sparger end was 1 inch above the bottom of the vessel. A few beads (20-30) were lifted off 4-6" from the bottom at $10 \mathrm{scfm}$ air flow. A significant number (80-120) of beads was lifted off at $30 \mathrm{scfm}$, but there was no cleared area under the sparger end. At $50 \mathrm{scfm}$, the number of beads lifted increased to $\sim 300$, but no area cleared of beads appeared. The entire bed of beads was vibrating. This was the limit of air flow that could be achieved and measured in the test rig.

Table 2-6 shows that for the notched-faced sparger, no lifting of the glass beads was observed until the sparger end was 1 inch above the bottom of the vessel and the air flow was $40 \mathrm{scfm}$ air flow (approximately 10 beads lifted). At $50 \mathrm{scfm}$, the number of beads lifted increased to $50 \%$ more beads at $40 \mathrm{scfm}$, but no area cleared of beads appeared. The bed of beads was vibrating over a 24” diameter area.

\subsubsection{Conclusions}

Based on the results of these tests, it may be concluded that:

- The sparger must be located within 1 inch of the bottom of the tank for effective lifting of $5 \mathrm{~mm}$ glass beads.

- The addition of notches to the sparger tip reduces the effectiveness of the air lifting operation by half. That is, at a given flow and sparger height, the amount of glass beads lifted or the area of the glass beads affected during the test with the notchedface sparger was only half of that with the flat-faced sparger. 
WSRC-TR-2004-00488, REVISION 0

SRNL-RPP-2004-00066, REVISION 0

Table 2-5. Glass Bead Behavior under Various Sparger Heights and Air Flows for Flat-Faced Sparger

\begin{tabular}{|c|c|c|c|}
\hline $\begin{array}{l}\text { Sparger } \\
\text { Height Off } \\
\text { Tank Bottom } \\
\text { (inches) }\end{array}$ & $\begin{array}{l}\text { Air } \\
\text { Flow } \\
\text { (SCFM) }\end{array}$ & Observations & $\begin{array}{l}\text { Extent of } \\
\text { Bubbles } \\
\text { Below } \\
\text { Sparger Tip } \\
\end{array}$ \\
\hline 6 & 10 & No movement of glass beads. & $1 / 2 "$ to $1 "$ \\
\hline 6 & 20 & $\begin{array}{l}\text { No bulk bead movement. Two to three beads directly below } \\
\text { sparger are beginning to move }\end{array}$ & \\
\hline 6 & 30 & A few beads directly below the sparger tip are moving. & $2^{\prime \prime}$ \\
\hline 6 & 40 & $\begin{array}{l}\text { Initial pulse generated affected zone of } 6 \text { " diameter directly } \\
\text { below sparger tip. }\end{array}$ & $2 "$ \\
\hline 6 & 50 & $\begin{array}{l}\text { No bulk movement. 8" diameter of vibrating motion directly } \\
\text { below sparger. }\end{array}$ & 3" \\
\hline 3 & 10 & No significant bulk bead movement & \\
\hline 3 & 20 & $\begin{array}{l}\text { No significant bulk bead movement. } 6 \text { " diameter vibration } \\
\text { zone directly below sparger. }\end{array}$ & \\
\hline 3 & 30 & $\begin{array}{l}\text { No significant bulk bead movement. } 8 \text { " diameter vibration } \\
\text { zone directly below sparger. Amplitude of Vibration } \\
\text { approximately } 1 / 2 \text { ". }\end{array}$ & $3^{\prime \prime}$ \\
\hline 3 & 40 & $\begin{array}{l}\text { No significant bulk bead movement. } 13 \text { " diameter vibration } \\
\text { zone directly below sparger. Amplitude of vibration is } \\
\text { approximately } 3 / 4 " \text {. }\end{array}$ & 3" \\
\hline 3 & 50 & $\begin{array}{l}\text { No significant bulk bead movement. } 20 " \text { diameter vibration } \\
\text { zone directly below sparger. Amplitude of vibration is } \\
\text { approximately } 1 " .\end{array}$ & \\
\hline 1 & 10 & 1 to 2 beads being lifted 4 to 6 " high on occasion & \\
\hline 1 & 20 & $\begin{array}{l}20 \text { to } 30 \text { beads lifted completely off bottom. The beads that } \\
\text { are being lifted are being immediately replaced by other beads, } \\
\text { leaving no clearing around the sparger. }\end{array}$ & \\
\hline 1 & 30 & $\begin{array}{l}80 \text { to } 120 \text { beads lifted completely off bottom. The beads that } \\
\text { are being lifted are being immediately replaced by other beads, } \\
\text { leaving no clearing around the sparger. Beads vibrating on a } \\
24 \text { " diameter affected zone. }\end{array}$ & \\
\hline 1 & 40 & $\begin{array}{l}\text { Approx. } 200 \text { beads lifted completely off bottom. The beads } \\
\text { that are being lifted are being immediately replaced by other } \\
\text { beads, leaving no clearing around the sparger. Beads vibrating } \\
\text { on a 30" diameter affected zone. }\end{array}$ & \\
\hline 1 & 50 & $\begin{array}{l}\text { Significant bulk bead movement. Approx. } 300 \text { beads being } \\
\text { completely lifted off bottom. Bottom of tank is not being } \\
\text { cleared. Entire bead bed is vibrating. }\end{array}$ & \\
\hline
\end{tabular}


WSRC-TR-2004-00488, REVISION 0

SRNL-RPP-2004-00066, REVISION 0

Table 2-6. Glass Bead Behavior under Various Sparger Heights and Air Flows for Notched Sparger

\begin{tabular}{|c|c|c|c|}
\hline $\begin{array}{c}\text { Sparger } \\
\text { Height Off } \\
\text { Tank Bottom } \\
\text { (inches) }\end{array}$ & $\begin{array}{c}\text { Air } \\
\text { Flow } \\
\text { (SCFM) }\end{array}$ & Observations & $\begin{array}{c}\text { Extent of } \\
\text { Bubbles } \\
\text { Below } \\
\text { Sparger Tip }\end{array}$ \\
\hline 6 & 10 & No movement of glass beads. & $1 "$ \\
\hline 6 & 20 & No movement of glass beads. & $1 "$ \\
\hline 6 & 30 & No movement of glass beads. & $1.5^{\prime \prime}$ \\
\hline 6 & 40 & No movement of glass beads. & $2 "$ \\
\hline 6 & 50 & No movement of glass beads. & $2 "$ \\
\hline 3 & 10 & No significant bulk bead movement & $1 "$ \\
\hline 3 & 20 & $\begin{array}{l}\text { No significant bulk bead movement. 3" diameter vibration } \\
\text { zone directly below sparger. }\end{array}$ & $1.5^{\prime \prime}$ \\
\hline 3 & 30 & $\begin{array}{l}\text { No significant bulk bead movement. } 8 \text { " diameter vibration } \\
\text { zone directly below sparger. }\end{array}$ & $1.5 "$ \\
\hline 3 & 40 & $\begin{array}{l}\text { No significant bulk bead movement. 12" diameter vibration } \\
\text { zone directly below sparger. }\end{array}$ & $2 "$ \\
\hline 3 & 50 & $\begin{array}{l}\text { No significant bulk bead movement. 16" diameter vibration } \\
\text { zone directly below sparger. }\end{array}$ & $2^{\prime \prime}$ \\
\hline 1 & 10 & $\begin{array}{l}\text { No significant bulk bead movement. } 3 \text { " diameter vibration } \\
\text { zone directly below sparger. }\end{array}$ & \\
\hline 1 & 20 & $\begin{array}{l}\text { No significant bulk bead movement. } 12 \text { " diameter vibration } \\
\text { zone directly below sparger. }\end{array}$ & \\
\hline 1 & 30 & $\begin{array}{l}\text { Bulk movement of beads on 3" diameter directly below } \\
\text { sparger. } 16 \text { ” vibration zone. }\end{array}$ & \\
\hline 1 & 40 & $\begin{array}{l}\text { Lifting a small amount of beads with a } 4 \text { " diameter zone of } \\
\text { bulk movement. }\end{array}$ & \\
\hline 1 & 50 & $\begin{array}{l}\text { Lifting approximately } 50 \% \text { more beads than at } 40 \mathrm{scfm} \text {. } \\
12 \text { " diameter of bulk movement and } 24 \text { " diameter of } \\
\text { vibrational movement. }\end{array}$ & \\
\hline
\end{tabular}


WSRC-TR-2004-00488, REVISION 0

SRNL-RPP-2004-00066, REVISION 0

This page intentionally left blank. 
WSRC-TR-2004-00488, REVISION 0

SRNL-RPP-2004-00066, REVISION 0

\subsection{FUTURE WORK}

No future work is planned or contemplated. 
WSRC-TR-2004-00488, REVISION 0

SRNL-RPP-2004-00066, REVISION 0

This page intentionally left blank. 
WSRC-TR-2004-00488, REVISION 0

SRNL-RPP-2004-00066, REVISION 0

\subsection{REFERENCES}

1. WTP-RPP-100, Rev. 0, "Interim Report, Technical Basis for HLW Vitrification Stream Physical and Rheology Property Bounding Conditions.”

2. WTP-RPP-98, Rev. 0, "Interim Report, Technical Basis for LAW Vitrification Stream Physical and Rheology Property Bounding Conditions.”

3. Test Exception 24590-TEF-RT-04-00024, “Test Exception to Test Plan, WSRC-TR2003-00532,” SRT-RPP-2003-00235 Rev. 0, 'Revised Test Matrix for Pulse Jet Mixer Gas Hold-Up and Release Testing,’ August 5, 2004.

4. Test Plan WSRC-TR-2003-00532, Task Technical and Assurance Plan in Support of the RPP Test Specification, "Pulse Jet Mixer Gas Hold-Up and Release Testing at Savannah River,” by H. N. Guerrero, December 5, 2003. 
WSRC-TR-2004-00488, REVISION 0

SRNL-RPP-2004-00066, REVISION 0

This page intentionally left blank. 